\title{
FAMILY AND LEGAL SUCCESSION IN ROMANIA - A CONCLUSION ${ }^{1}$
}

\author{
DOI:10.24193/SUBBiur.62(2017).1.1 \\ Published Online: 2017-03-15 \\ Published Print: 2017-03-30
}

\section{Mircea Dan BOB*}

\begin{abstract}
We conducted from October 2011 up to November 2016 a research on the evolution of the family concept and its influence on the legal succession order in Romania. Our scope was to provide an in depth analysis of the complex social, historical, philosophical and religious factors who worked together in modern and post-modern Romanian civil law history, in order to evaluate the answer given by the recently enacted civil code of 2011.

The paper hereby can give an idea on the conclusions we drawn at the end of our work. It argues mainly if the new provisions are covering all the aspects drawn into practice by the family - in its traditional and recent presentations. We focus on the successive versions of the civil code's Book dedicated to the Law of successions, part of them being authored by ourselves. We take into account the recent evolutions in the Family law and in the Law of successions of several European and nonEuropean countries, with a special accent on France and the Canadian province of Québec - who deeply influenced the former and the present Romanian civil codification.

The research ends with a set of conclusions leading to de lege ferenda propositions, meant to improve the actual state of the new Romanian civil code on the emphasized subject. They are meant to satisfy the specific needs of the present day Romanian society and to keep in touch with the tendencies we drawn out of the experience of comparative law of successions.
\end{abstract}

Keywords: law of succession, heirs, surviving spouse, civil code, family, comparative law, reform

Cuvinte cheie: drept succesoral, moștenitori, soț supravieţuitor, familie, drept comparat, reformă

1. By examining the VIth century reform undertaken by Justinian on the legal succession framework, we can note that he completely established cognation (blood kinship) as the fundament for the $a b$ intestato devolution. He prioritized the entitlement to inherit in respect to the successor's degree of closeness to decuius, in a specific order in which - by comparing the 118 and 127 Novellae to the corresponding provisions of the Romanian New Civil Code - we cannot single out fundamental differences. The ridiculously inadequate successional status of the surviving spouse was corrected through the 53 and 117 Novellae, 
which regulated the usufruct of the poor widow. The resolve existed in the codifications pertaining to the ancient Romanian law, from where it was translated to the regulations of our Civil Code during the 1865-1944 interval, after which it was replaced with the more equitable solutions demanded by the conceptual evolutions of the modern times ${ }^{2}$.

The amazing similarities over the course of its evolution in time once again demonstrates the extraordinary stability of the field of the law of successions in respect to other branches pertaining to the private law arena. The valor of the greek and latin classical literatures resides in the universal manner in which they managed to capture the human essence. Similarly, an area so intimately connected to then private existence of the human individual in general such as the field of successions cannot suffer fundamental alterations, and the basic blueprint of the successional devolution cannot become essentially different unless the elementary tendencies of each and every one of us would be forsaken. The before-acknowledged perennial nature explains why the state of the European unification in this field is the least advanced, an area where the current Bruxelles-generated trends although extremely active in the latter years - do not move past harmonizing procedural regulations and ones pertaining to the field of private international law ${ }^{3}$.

But if the fundamental architecture remains unchanged, the details of the regulations depend on the particularities of the moment and place in which we examine them. This explains why the main question that initiated our research endeavor was: does the Romanian New Civil Code acknowledge the evolution of the concept of family in the manner in which it regulates the legal successional matter?

2. Any reform implies, without any shadow of a doubt, a destructive impulse destined to highlight a separation from the past and to showcase the promised novelty. As far as the Romanian New Civil Code is concerned, developments took a different path. The new regulation assumed the old solutions, reuniting the civil and commercial aspects in the same legal framework, and consequently created the effect of an open accumulation of ideas, norms, institutions. The addition prevails over the purifying effect, while allowing the old aspect to shine through in a victorious effect of at least substantial proportions. This is not to say that the New Civil Code would highlight legislative novelties, but only that reform has been undertaken in a gentle manner, without sparking a great revolution, an important deviation from the old aspects being thus avoided 4 .

Why has this status quo been reached? Because the civil codification reform was a doctrine endeavor, a result of the experience of some experts who have solely displayed their theoretic and practical horizons of strict competence in the matter. The sociological, religious and family policy-prospective implications have at most played an indirect role in the regulations' drafting process, to the extent that they were implicitly distilled in the legal experience of the members of the Commission tasked with the drafting activity.

It has been easily noticeable over the course of this work how the French legal transplant that occurred in the XIXth century (in the field of the successional rights of the spouses) was not adapted to the realities and patrimonial requirements of the Romanian family structure specific to the XIXth and beginning of the XXth centuries. Moreover, it 
trampled both the customary as well as the written law traditions (both multi-centurial) of the privileged standing of the surviving spouse in both the family and successional rights' aspects. The reform of the latter's hereditary rights was ardent also from another standpoint: the matrimonial legal regime under the old codified regulation was of a dowry nature (conventional separation of goods). Its cessation upon the death of a spouse that - due to mismanagement or through mislead cunning - had depleted the underlying value of the dowry fund, would keep leaving the surviving wife in a precarious, vulnerable financial position.

Overall, eight decades were necessary in order to straighten these matters (from 1 December 1865 to 10 August 1944). The great length of time may suggest the fact that the damage caused by the Cuza Code would not have been that substantial. If the legislative decision reached by his Commission was as unfounded as we hold it out to be, why has it taken until 1944 to retrieve the traditional solution of the ancient Romanian law, in that the widow should be viewed as central to the matter at hand? In addition, why was it that at the enactment of the reform, this tradition was not brought up instead of the texts of the German Civil Code (art. 1931 and 1932) - which were the source of reformatory inspiration in the matter of the successional rights of the surviving spouse?

The answer can be distilled in two separate planes.

3. The first is one of primarily historic nature. The destructive of legal tradition and disregarding of practical reality solution of the Civil Code was the normal consequence of the cleavage of the Romanian society at that time. The latter was practically divided between a cultured minority, which lived in awe and admiration of the progress made by the most advanced civilization of that time (the French one) and an absolute rural-based majority (not exclusively of peasant nature) which consistently refused to accept the enactment upon it of the formal but unsubstantially-relevant Code of 1865 . The slow pace of the parliamentary legislative process has added difficulty to this issue. The causes of this slow reaction time are not rooted in systemic dysfunctions or any personal incompetency of the members of the legislature. We consider that the apparent slow nature finds an explanation in the fact that reaching any decision is always impacted by the momentary interests and personal prejudices of those called to participate in the process of taking it - normal circumstances arising in the implementation of any legislative reform in any society in any historical epoch. Establishing status equality between the legitimate and illegitimate children constitutes an act of courage for a pater familias: this automatically confronts him with the reaction of the legitimate family, in a society that at the end of the XIXth and beginning of the XXth centuries was still too closed to such an attitude of openness. Sexual prejudices had, on the other hand, enough weight in order to not look very favorably upon the legal emancipation of women.

The second plane is one of legal nature. All the authors who demanded the revision of the Code's provisions regulating the rights of the surviving spouse have invoked the tradition of our Ancien droit. However, the passing of time makes any abandoned legal solution to pale in the conscience of the justice seekers: forgetting does not discriminate, no matter how unjustifiable the consequences of the abandonment. The social and historical contexts in which it used to function are inevitably changed. Other circumstances, other issues and other 
approaches to the matter at hand will have inevitably replaced it, so that its direct recovery, as such, becomes impossible. The development of comparative law approaches and the (then) prestigious nature of the freshly enacted German Civil Code have placed it on a standing of a more comfortable and credible reference point than its past-ridden counterpart. Let us not leave aside the historical and political context: the successional reform of 1944 intervenes amidst a time of war and after the recent failure of a New Civil Code, that solved the issue at hand, being - probably - considered a faster and more readily available solution.

By taking a closer look, this fact (corroborated with the insufficient importance given to the historical understanding of the issue at hand) appears to us to constitute the cause of perceiving the legal community regime in the inexact standing of the typical standard of the Romanian legal tradition in the matter of legal matrimonial regimes. From here, derive the insignificant changes enacted starting with 1 October 2011 to alter the successional rights of the surviving spouse. These do not amount to a stringent issue anymore, as long as the liquidation of the legal community matrimonial regime (overwhelmingly used in the practice of modern times) place the widow/widowed on a pole position as far as the perspective of the successional division process is concerned.

4. In our view, the New Code can receive critics on two additional fronts.

On one hand, its content only acknowledges the strictly recognized particularities of the property rights of the Romanian family, without taking a prospective approach. By exception from this approach, we must note the regulation of the preciput ${ }^{5}$ clause (art. 333 of the Civil Code) and the introduction of the fiducia (art. 773-791 of the Civil Code). The last two were enacted by observing the provisions of the French model and, respectively, by corroborating the addition that was made to the French Civil Code by Statute 2007-211 of the 19th of February 2007 with the North-American-inspired reform of the Québec Civil Code in $1994^{6}$. We left out a reference to the matrimonial regimes, because their reinstatement was an older demand of the Romanian society.

On the other hand, realities derived from the advancements in science and technology, which generate radical changes in the area of family and successional rapports, are not present in the code. The best example for this is that of modern procreation methods, analyzed in the previous chapter. By going through the current Civil Code's provisions referring to medically assisted human reproduction, kinship and inheritance, it becomes obvious they leave out issues that create numerous problems in the course of real life. This aspect is worthy of criticism, given the fact that all of the already showcased issues have not once, but plenty of times made themselves available to the analysis of the jurisprudence of other States, whose legislative frameworks constituted the basis for the current Civil Code. They also exist in the Romanian society, even if they have not yet made their way into relevant case law.

5. Moreover, the Commission subordinated the manner in which it regulated the realities of the family property law that are discussed herein to the political framework of the then-governing party. A member of the Alliance of European Christian-Democratic Parties, it 
has imposed a moralizing definition in the traditional sense upon the notion of family, while at the same time it has self-limited itself in viewing the family purely in its classical displaying ${ }^{7}$.

Are these two aspects good or bad?

The tie between the political and the legal was and continues to be a source of debate in the legal philosophy arena. The only certainty that appears revealed to us is that the influence of the political views of the governing power at a certain time upon its legislative endeavors is an aspect that derives from a normal functioning of the normative activity. On the other hand, though, the drafting of the new civil law framework should have taken into consideration the activity of the Report that accompanied the final draft of the not yet enacted Romanian Civil Code of 1940:

„A law [...] must account for the ever-changing and live realities, for timeless tradition, for the succession of historical events on the basis of which the present itself is being formed, for the soul of the nation. The present, stripped of the analytical power commanded by the past, represents 'a closed book'. The creation and function of the law is thus not unique and ultimate, subject to disorganized and random inspirations. Civil law must keep up with the times and heed the command of the new realities that demand wide recognition (our highlighting - MDB). Tradition, infused with the power to keep matters of durability, necessity and mental acuity, joined by the need to evolve by the power to create, with moderation and foresight, makes for solid and lasting support for the civil legal existence itself." ${ }^{\prime 8}$

Therefore, we predict that issues may appear in the event and to the extent that the European wave of changes to the conception upon the notion of family will affect Romania as well. Moreover, this will constitute a mere starting element for the recognition of realities that already exist in the Romanian society. We will expand upon these issues, starting with the tendencies that we have noticed in the comparative law sphere (a) and then by dealing with the internal realities and tendencies (b).

6. (a) We organized an international conference hosted by the Romanian National Union of Notaries Public in April 2013, in order to disseminate the project's results ${ }^{9}$. The participants to the gathering were legal scholars and practitioners (notaries public and lawyers) from France, Québec, Belgium and Romania, who have debated and imparted knowledge and experience upon each recent event within the ambit of family law and legal devolution.

7. In Québec ${ }^{10}$, the legal status of married couples and that of couples living in factual communion differs greatly. The Canadian Supreme Court held that ${ }^{11}$ the Civil Code provisions regulating the patrimonial aspects of marriage (marriage effects, matrimonial regimes, alimony and successional potential) are Constitutional and in accordance with the provisions of the latter fundamental document, they do not apply to cohabitants (merely factual spouses). The debate that was initiated in the context of the ending of a situation of a factual cohabitation did not address the field of successional potential. Given that the highest court of law has decided, the judicial debate is currently closed. The issue is however still not resolved, due to the fact that the Court's opinion was far from unanimous ${ }^{12}$. The ball now 
rests in the lawmaker's court ${ }^{13}$. The stakes are high, given the fact that the faith of the legal status of more than a third of Québec's couples is on the line.

In this way, 36\% of Québec's couples continued their evolution outside the realm of legality ${ }^{14}$.

However though, couples are heterogeneous - if we are to take into account the central family structure, the childless couple, the second union, the recomposed family out of which common children were born or not etc. This sociological reality can be found both in the case of factual cohabitant couples, as well as in the case of married ones. A priori, it is natural that we question the coherence of a family law that directs provision proposals (many of them imperative in nature) to married couples. And that by doing this leaves more than a third of Québec's couples in a normative territory outside legal regulation, the latter category actually cohabiting factually and often times being constitutive of a family with children. Indeed, $60 \%$ of the children from the French-speaking province are born outside the traditional marriage structure. If, in this context, it may appear normal to some to extend the rights to the factual cohabitants as well, would not the framing of the legal regime applicable to married couples have to be reconsidered as well ${ }^{15}$ ? Would not the legal provisions have to be adapted in order to take the heterogeneous couple structure into account, rather than imposing a rigid framework upon all the persons wanting to become married?

It is considered that the Québec lawmaker might draw inspiration from the common law model of the Canadian provinces, and therefore assimilate the factual cohabitations to marriages after the passing of a certain period ${ }^{16}$. In this case, must the factual cohabitants be assimilated to married couples under all aspects (alimony, division of family property, successional potential) or just under some of these? Moreover, what timeframe should be desirable? Factual cohabitation starts out as a simple trial period for many couples. In the event of expanding the regulatory sphere, should the factual cohabiting couples then be allowed to choose an opting out type of strategy ${ }^{17}$ ?

Other thought process have been proposed as well. For Goubau, Otis and Robitaille, the principle of the autonomy of choice of the factual spouses must give in to a requirement for protection, having the purpose of ensuring the primacy of the interest of the child. They have examined a series of statistics that proves, on one hand, the economic hardship in which mono-parental families find themselves following a breakup and, on another hand, the acknowledgment of the fact that in Québec children are born, in their great majority, from factual cohabitant relationships. Then, they have concluded that the provisions applicable to the factual spouses need a revision to the extent that they refer to the children stemming from these families. To this purpose, they emit a pathway to reflection in the fact that „the rights that are traditionally linked with the institution of marriage will in the future, in the name of the family's interest, be preferably contingent solely on the presence of the children, rather than the matrimonial regime of the parents ${ }^{18 \prime}$. Thus, in the presence of the common child in the spouse's care, the provisions regulating the family goods, the family home and the alimony will be potentially activated. 
Jarry proposes in equal measure that a limitation be imposed on the lawmaker's intervention in respect to factual spouses that have children, but under a much narrower angle. She is of the opinion that a compensatory alimony obligation should have been imposed between the factual spouses when they have children in common, which should draw inspiration in its quantification from the Optional guidelines in the matter of spouses' alimonies ${ }^{19}$. This alimony obligation would be „fundamentally-linked to a compensation for an uneven contribution of the spouses for bearing the family duties imposed by the children's education." 20

Alain Roy tackles the issue in a more Global manner, where the interest in his thinking also derives from. He highlights from the very beginning the fact that the legal regime applicable to married couples is probably too rigid $^{21}$. By examining the matters at hand from the perspective of the matrimonial Statutes, he highlights that the regulations could have been modified in accordance with the rank of the marriage or the spouses' age. Still, he expresses the opinion that the fundamental idea of the current matrimonial law - which defines marriage in a sense that requires an economic association - is false. It is not the marriage in and of itself that attracts a spouse's economic vulnerability, but more overtly the presence of a child. He places the emphasis on a family law that is fundamental not on the marital status, but on the distinction between the couple with or without children, without concern for the fact that they are married or not. The current legal framework would apply to all of the couples with children who would benefit by the grant of legal protection (protection of the family home, family goods, community of goods, alimony obligation), while the framing of the childless couples would be reduced ${ }^{22}$. The status quo would then be maintained for the childless couples living in factual communion, while the married couples without children could opt out of the applicability of the current imperative provisions, especially those regulating the family's patrimony.

8. More recently, the consultative committee tasked with family law proposes a very different approach ${ }^{23}$. The fundamental premise is based on the fact that the economic interdependence and the economic vulnerability of a spouse stem more from his parental responsibilities, rather than the means of choice of couple life. The Committee proposes that the family law focused on the "parental" trait and on the common responsibility, deriving therefrom should be rebuilt. In this direction, it proposes, under the caveat of a dissident member ${ }^{24}$, that a special parental regime that would apply to any parent regardless of his conjugal status (married or not) should be enforced. This mandatory parental regime ${ }^{25}$ would require any parent to contribute to the familial costs to the extent of his respective aptitude. It would extend the applicability of the rules regarding the protection of the family home to all the parents. Finally, it would enact a parental compensation obligation, in order to make up for the economic deficiencies to which the parent who cares for the common child was subjected. The obligation would encompass the restrictions that were suffered over the course of the cohabitation, as well as those that will be incurred following the breakup due to the division of the parental roles. The Committee at the same time 
proposes a conjugal regime ${ }^{26}$ that formally acknowledges the two means of conjugality as being allowed by the Civil Code (marriage and factual union) and that grant privilege to the autonomy of will and contractual freedom.

This freedom manifests itself through an opting in type of logic for factual spouses and through an opt out type of possibility for married persons. The patrimonial consequences of the marriage would sensibly be the same as in the present, under the reserve of the spouses' possibility to renounce them through the matrimonial contract. This reform proposal is a major one for married persons. The family patrimony would become the legal matrimonial regime and would cease to have an imperative nature ${ }^{27}$. As far as the factual spouses are concerned, they could subject themselves to it through the union contract. This opting in or opting out type of logic also constitutes the basis for the Commission's stand as far as the successional vocation is concerned, making the autonomy of will prevalent and leaving the factual spouses with the right to include their partner in their will ${ }^{28}$. Thus, in a broad view ${ }^{29}$, the Committee proposes on one hand an imperative parental regime that would apply to all couples with children - married or not. On the other hand, the Committee proposes that the status quo be maintained for the factual unions as far as the conjugal regime is concerned and relaxes the legal framework for married persons, allowing them to insulate themselves from the regulations concerning the family patrimony.

Should we draw a distinction between the status of „parent" and that of "spouse”? Must we create two systems of parallel regulations - meaning an imperative parental regime distinct in respect to the conjugal one, in accordance with the proposal of the majority of the Committee's members - or should we favor the dissident stand and subject the factual couples to the rules of marriage when they have children? Can it thus be concluded that the solution resides in the distinction between couples with or without children? It is an at least interesting lead, because, the revision of family law should not be limited to reviewing the legal framework applicable to couples living in factual union. It should also allow for the reevaluation of the rules applicable to married persons, with the purpose of easing the framework applicable to them, at least as far as patrimonial rapports are concerned. The profile of the couples has changed considerably during the last decades, and the legal framework that is currently in force is outdated.

The lawmaker has not until now acted upon the proposals set forth by the Consultative Committee in the matter of family law, which leaves room for the speculation that it has not bought into the idea that family law should be restructured by dissociating the rules applicable to parents by those regarding conjugality.

If it decides to place an emphasis on extending certain rules that are applicable to married persons to the category of factual spouses, it will not be able to leave aside the issue from its successional law perspective. Indeed, the matrimonial status is the source of the successional vocation. If the matrimonial status is to be replaced with the recognition of the conjugal state in the event of the child's existence, how will it become justifiable that the spouses receive a different treatment from the successional standpoint? The matter 
will be raised the same, if the lawmaker would instead choose to extend the rights of the factual spouses after a few years of cohabitation.

The impact of this modification upon the law of Québec would surely be greatly reduced if the end of the cohabitation would be generated by death. In the absence of a successional reserve, the ruled of the legal succession can be removed through the will, which in turn allows for the joining of equality with the autonomy of will.

Still, if the rules of the legal devolution are set in motion, the influence of the law's modification risks attaining a much higher degree of importance from a successional standpoint rather than in a context of separation, in which only the matrimonial rights are exercised. Indeed, the union's duration may influence the quantification of the alimony obligation, as far as the content of the goods that form the family patrimony and the groups of divisible common goods are concerned. The proprietary goods are excluded from the separation procedure, and the net value of the goods that were received before the union and the corresponding additional value are not included in the separation procedure.

The personal rights resulting from the division of the family's patrimony and from the division of the mass of common goods become reduced in the same proportion. However, in a successional context, the hypothesis changes completely. The factual spouse will be able to inherit a part or the entire patrimony of the deceased, without having the union's duration bear any influence upon the quota he is entitled to receive. The sole important element will be his standing as surviving spouse at the time of death ${ }^{30}$. It will then be mandatory for the lawmaker to seriously tackle the issue of defining factual spouses, for the goal of determining those who may prevail themselves of this status. Another difficulty then risks emerging, in that the starting date of the factual union and the end date of the cohabitation have to be determined. While the successional vocation of the married person ends upon death, that of the factual spouse will be terminated at the end of the cohabitation, a date which can sometimes be difficult to pinpoint. Another issue that will reveal itself is the matter of knowing whether a factual separation reflects a climate of couple crisis, in which case cohabitation is only temporarily interrupted, or rather if this separation reflects a final break, which will annihilate the successional vocation.

Changes in conjugality statuses thus confront law and in Québec leave room for noticing modifications in the patrimonial family law. Will they merely refer to the extension of certain patrimonial rights? Will they extend to successional rights as well? The future will decide whether the surviving factual spouse will become a creditor, an heir or will be a stranger to the successional process.

9. We thus see how the mono-parental family is an extremely frequent reality in Canada (just like in the whole of North America and in Western Europe), and that so are unmarried couples and children born outside marriage. The legislative incursions, which appeared in the first two decades of the third millennium in the above-mentioned geographical regions, are eloquent as far as the awareness of the existence of these realities is concerned. 
„In Paris, as is the case in London, the majority of the households are comprised of a single adult. Such a decrease amplifies the demand for housing and radically alters capitalist theories in the area of family. Instead of the close-knit and isolated central family, we have to deal with an even smaller family unit, dispersed and fragmented, that doesn't even represent a family per se, if by this term we mean a couple that lives with children in the same housing unit. The family on the corn cereal box proves itself as not the final stage of modernization, but as an outdated stage within the evolution of the concept of family." ${ }^{\prime 1}$

We must observe ${ }^{32}$ that, before the successional reforms of 2001 and 2006, the French lawmaker froze the evolution of societal standards by enacting its Law of the 15th of November 1999, on one hand by establishing the existence of the state of cohabitation through the notion's first definition from the Civil Code, deemed as factual union. On the other hand, by creating the CSPA (Civil Solidarity Pacts) institution: „the contract entered into by two private persons of age, of different or same gender, directed at organizing their life in common". These two unions not amounting to marriage however only have limited civil consequences: the fact that the cohabitant does not enjoy any legal standing does not grant him any successional right in relation to the surviving cohabitant.

As far as CSPA is concerned, numerous regulations have been enacted in order to bridge the gap between this contract and marriage. Still, as far as the civil law arena is concerned, the surviving partner does not have successional vocation - except for a protective regime, as far as the home is concerned (he has the right to enjoy using the couple home for one year). This lack of the partner's successional vocation was without a doubt one of the causes for the 2013 reform named "marriage for everyone", which transformed the spouse, even if of the same gender, a spouse as any other, enjoying the same rights of a spouse part of a heterosexual married couple. Nevertheless, as is the case for married couples as well, there is a strong fiscal incentive for drafting last wish provisions in favor of the surviving partner, the right to inherit the partner enjoying a complete tax exoneration. This is one of the explanations for the CSPA's success, which was initiated at first more in favor of homosexual couples, but is today used by over $90 \%$ of the heterosexual couples.

As a side note, some statistical data may prove interesting. One out of two children is born outside of marriage (as opposed to only $6 \%$ in 1960); $40 \%$ of the marriages end in divorce; apparently, there are sixteen million couples, out of which $72 \%$ are married and 700.000 are CSPA couples - which means close to four million couples living in free union. 200.000 French nationals declared that they live as part of a homosexual couple; $80 \%$ of the successions are taking place in an ab intestato manner. One French study thus drew the conclusion $^{33}$ that the natural family model replaced that of the family established upon marriage. Today, marriage does not constitute a basis for the family's formation, but together with the CSPA and the cohabitation - is just another model for living as part of a couple: the French citizen chooses his most financially and socially-advantageous option from the available ones. The 2013 recognition of the homosexual marriage has definitively detached marriage from the concept of filiation. The family is created at the very moment a child emerges, a fact that constitutes its basis. 
In a synthetic overview of everything that we have showcased so far over the course of points a) and b) above, we may transpose a sociological conclusion drew in regard to the situation in Great Britain:

„For the majority of the people in Great Britain today, the couple, married or not, is the basis of the family. The couple begins to take central standing as far as family life is concerned, as the economic role of the family begins to decline, and love, or love and sexual attraction become the basis on which marital ties are formed (even though [...] the notion of "family" should not, in any case, be limited to refer to heterosexual couples and their children alone)." ${ }^{\prime 34}$

10. The first "Copernican Revolution”, as some have named it, in the field of Belgian successional law ${ }^{35}$ stems from the Law of 14 May 1981, whose objective was conferring a spot of full right enjoyment to the surviving spouse when going through the legal successional devolution process. The latter is placed on a standing of an heir enjoying full rights, just like those of the blood-related legal heirs; in addition to the rights already secured to him through the liquidation and division of his matrimonial regime, he is granted the usufruct upon the entirety of the deceased's succession.

As long as he will continue to be alive, the surviving spouse keeps, exclusively for his benefit, the usage and enjoys the deceased's goods. However, his children or their descendants instantly enjoy the benefits of the nude property, and therefore they become insured of the availability of the full ownership rights over the successional goods starting with the day in which the surviving spouse dies. The law of 1981 also predicted the possibility of the spouse's usufruct to be converted to full ownership, a measure which needs approval from the court (art. $745^{4}$ be.). The option was very frequently used in practice in the situations where misunderstandings appeared between the descendants and the surviving spouse - in spite of the mandatory judicial censorship. The court's control is not necessary when the spouse competes against heirs other than the descendants ${ }^{36}$.

Up to this point, nothing affects, in principle, over the course of a more or less long term, the destination of the family's patrimony. The family vision, as the Belgian lawmaker understood it during the preparatory efforts for the Law of 14 May 1981, became very different from that of the Napoleonic Code's authors, but the logic behind the legal successional devolution remained fundamentally infused with a family type of nature.

The reform performed based on the Law of 14 May 1981 was supposed to be balanced, by parting the successional devolution between the surviving spouse and the children, both categories benefiting, following the death, from the family's solidarity presupposed to be shared within the ambit of the "home". But as families became divided, remarriage following divorce phenomena multiplied and solidarities shared within the recomposed family arena came to a halt, it was proven that the law (combined with other patrimonial provisions that are susceptible of being taken by the spouses, and moreover, due to the adoption of their matrimonial regime) created instruments that allowed the surviving spouse to attain a privileged status to the detriment of the children and thus affected the passing of the patrimony, in the ambit of the family, to the next generation ${ }^{37}$. 
We know that what would characterize contemporary society - frequently qualified as "post-modern" - is the fact that it had become "individual”. By this, it is to say that the reason for the existence of the individuals would be less and less subordinated to a collective directive - be it national interest or family interest, their personal interest being, to the contrary, self-fulfillment. From such a perspective, the institutions organized by the society and by the State would progressively lose their role of achieving the general interest - which is harder and harder to understand on the other hand. It would also be more and more guided by the recognition and protection of the individual's private interests, the latter ultimately being the focal source for his own understanding and identity-seeking. Because the privatization and targeting of the values and normative guidelines leads almost inevitably to the expansion of the field of autonomy and self-determination of the individual: who can decide better than "one" "for oneself"?

In the context of this liberalism - which determines the entirety of the fields of human activity - one might understand the evolutions that completely disturbed, starting with the end of the XXth century, the vision of the family and family relationships. These evolutions were, however, even more radical within the ambit of private and family life, especially due to the fact of perceiving private and family life as by excellence constituting the place of self-fulfillment and personal development. Do we continue to believe to this day that we can state that the family would be "the basis of Society"? Don't we, instead, believe that the purpose of the affective and family relationships would have become purely private in nature? And that to the extent in which it would not have been justifiable, because as far as they correspond to the feelings of love and happiness as perceived by the individual, the consequence that each of them should have been free to determine would be that corresponding to an own perception regarding love and happiness?

This issue is surely not more than a general view, which is not unanimous and for which there would be serious reasons for us to believe that it is infused with great degrees of illusion and fantasy, alike, on the other hand, the ideology of the political and economic liberalism. It is true that every reform that has recently intervened in the legal provisions concerning the human body, and, more generally, human life, sexuality, marriage and couple, family bonds, vulnerable persons were inspired by this individualistic vision regarding family and family relationships. It would have been odd that successional law should escape, although, as was already observed, the reforms are probably much slower in pace and less radical in their consequences.

11. In the Belgian law, these reforms are not yet (at the level of the year 2013) but in a project status. And this even if the grant of a successional right to the legal cohabitant through the Law of the 28th of March 2007 is already sufficiently important in this new way of thinking. The ideological reasons which inspired this reform and which will inspire future reforms stem, precisely, from this individualistic vision regarding the family. We must especially take note of the following: 
- the prominence granted to the couple and to the feelings shared within the couple, which tend to favor a horizontal view upon the succession's passing on to the detriment of intergenerational passing on;

- the will to suppress the reserve rights of the ascendants (as was the case in France in 2006, but in other countries as well) and to reduce the rights of the heirs enjoying rights to a reserve, both as to their extent as well as to their very nature. This is because the reserve won't represent but a reserve in value, with the consequence that any person will be able to extract its patrimony from the family, including the patrimony received by itself from its parents, while the children and the descendants won't receive anything more than „money";

- the value of the individual's programming of his succession and of the ante mortem successional contracts (successional planning).

All these reforms are founded on the premise that, first and foremost, a person's patrimony or a couple's patrimony belongs to their respective owners and that it must be left up to them, including in so far as concerning their children, to decide upon its usage. Then again these children will not be called upon anymore to receive that very specific patrimony from their parents or their grandparents. They will merely receive a pecuniary compensation thereof. Finally, that parents and children will from now on have the capacity to enter, freely, into contracts meant to regulate the passing on of this patrimony at the date that the parents become deceased.

The market economy largely inspires these ideas and they reflect the progressive decline of the mandatory within the family destination of the patrimony. But is it true and adequate, on one hand, to transpose the prevalence of the fact that the liberal economy is focused on the money aspect, even when concerned with the issue of family relationships, as far as the intergenerational passing on of goods and objects which belonged to their parents and grandparents, rich in historical meaning, memories, affection? On the other hand, is it true and adequate to renounce that which up to the present moment was perceived by us as being a last veritable pillar of a family order: the unconditional nature of the family relationship bond?

12. (b) Historical and sociological studies carried out throughout the current territory of Romania proved that, starting as early as the XIXth century and despite the efforts of the Church to the contrary,

"Just like celibacy and the widowhood, cohabitation became in time an alternative to marriage in the ambit of which family-type relationships were bound between two partners and the children resulted from their cohabitation" 38 .

We must state here that, in a just way in which one author has demonstrated ${ }^{39}$, cohabitation cannot be placed without clarifications within the category of the forms of family erosion. Various social, financial, religious or/and contextually political specific impediments made the people of the age enter into consensual unions accepted by the community as helping establish the concept of family ${ }^{40}$. A thorough research showed that 
it the laic spirit of modernity was not the determining factor in the spread of cohabitation, but the random specific situations in which those involved found themselves ${ }^{41}$ :

"Secularization, which made consistent progress towards the end of the XIXth and beginning of the XXth centuries, facilitated the modernization phenomenon, however determining were the social-economic evolutions which followed the disappearance of the feudal relationships and the building of a society based on market economy and industrialism, which massively affected the individual and the community. [...] What resulted was a clear individual emancipation and a freeing of family and matrimonial relationships to the extent of the entire population." ${ }^{42}$

Indifferently of the hypothesis though, the practice of cohabitation has eroded the formula that the Church predicated for the family.

More serious "slippages" of the concept of the traditional Romanian family began appearing as early as the end of the Second World War, when the rate at which families disbanded grew exponentially. This phenomenon took place due to the fact that the fathers returned home, and were confronted with the fact that their wives have grown accustomed to dealing with daily activities on their own and with the children that didn't recognize or even know them anymore. The numerous divorces have brought to Romania for the first time the attention to the reality of the single mother and of the mono-parental family, even though these notions did not appear in the official propaganda ${ }^{43}$. The brutal ideological switch to communism after 6 March 1945 came to accentuate the destruction of the traditional call of religion's moralizing authority, with a direct influence upon the family behavior $^{44}$. Our conclusion should not be surprising, as it is built on the comparison, for example, with the situation reported in the north of Oltenia at the beginning of the XIXth century, when the Christian moral is identified as one of the factors that determined a very low frequency of divorces ${ }^{45}$. Matters have then turned following the year 1950 to a path that led today and our authors (following the footsteps of the western and NorthAmericas ones) to launch definitions that strive to define the mundane reality:

„The family is a social group, which may or may not include adults of the both genders [...], may or may not include one or more children [...], who may or may not have been born out of their marriage [...]. The relationship between the adults may or may not have originated in marriage [...], they may or may not share a common home [...]. The adults may or may not be cohabitants of a sexual nature, and the relationship may or may not involve socially valued feeling, such as: love, attraction, respect towards the elders and admiration." ${ }^{\prime 46}$

The described reality also derives from the consequences of the second and third industrial revolutions (those of the first industrialization were already tackled in the chapter referring to the Old Civil Code) ${ }^{47}$. The second half of the XIXth century had promoted throughout the Western civilization the image of the woman that does not leave the household, men having jobs sufficiently well-paid in order to be able to provide for the entire family. The previously-mentioned revolutions had gone so far as to completely change this view, a fact also attributed in the second half of the XXth century - beginning of the XXIst century to the rises of the living costs in the consumer society. The vicious circle becomes complete once we observe that the consumer goods that have systematically freed the 
woman from a great deal of household chores that were consuming of effort and time (electric household appliances, for example) have a high acquisition value. This fact mandates that both spouses work, because they must additionally bear the household costs, those of (their) car, and of leaves of vacation - and the activation of the good consumer is indispensable, because the production of consumer goods supports the economy and stabilizes the labor market.

These aspects fundament two interesting consequences for our research: the switch between traditional family roles (fathers dealing with raising the children ${ }^{48}$ ) or the neglect of the children by the spouses which are highly involved in their careers, children whom the parents support with financial resources destined for their education and whom receive encouragement to rapidly become involved in active life ${ }^{49}$, respectively the at the very least equal standing (from the standpoint of the financial contribution to the wellbeing of the family unit) that the wife enjoys ${ }^{50}$.

13. Let us accept, for the sake of the argument, that all of the before-mentioned Western society characteristics are correct and they supersede (with a chronological delay estimated by one author to be a hundred years ${ }^{51}$ ) the Romanian reality. Even so, we must also take into account an additional aspect displayed by our society: the consequences of the massive expropriations and of the intensive urbanization, pursued as (communist) State policy before $1989^{52}$. The serious imbalances that were created due to the population relocations as a consequence of forced cooperation and nationalizations, as well as due to territorial systemizing (e.g., Statute 59/1974), made it so that at the current moment Romanian urban and rural lifestyles are not fundamentally different:

„The peasants which were disinherited overnight have transported behaviors, attitudes and specific rules corresponding to the natural environment in which they were formed and grew up to their new destinations." 53

„The waves of peasant relocations to the urban landscape brought with themselves traditional values, which were disintegrated by modernism with great difficulty. This explains why the family, in Romania, is held to such a high regard, why the family cultural model has not been subjected to erosions, why the concept of family remains a constant of the Romanian society, in spite of the current turmoil." 54

The above-quoted text has the great quality of being a particular conclusion highlighting a high degree of abridging. In order to detail its consequences, it one has to note that Romania sets forth a strong conservative attachment towards the classic family. This often slides on the slope of intolerance, due to several factors:

- increased level of religious adherence, with frequent radically religious adherences, also favored by the divide created by the economic issues that followed the Revolution;

- the population's low literacy rate, created mostly by the pre-1989 era and in part to the post-revolutionary promotion of success in life stories of certain "businessmen" with precarious education levels;

- the chronic mistrust in others - inherited from the communist period;

- the reduced degree of social and relational capital ${ }^{55}$. 
Recent sociological research have displayed the same, and have proved that the concentration of the concept of family cannot be made absolute in Romania. The financial problems, those regarding caring for the children as long as both parents are involved in the workplace and the need to assist the ascendants that have reached old age are still aspects that are supportive to the survival of parts of the cooperation exhibited by the extended family model ${ }^{56}$.

14. This also explains the size of the current movements that are dedicated to restore the "traditional family" concept. One of the main coordinates on which our analysis was based was the religious one. The Romanian Orthodox Patriarchy declared the year 2014 to be "The year of the family". The motivation was a complex one and, in the research we have pursued, we adapted it through an interpretation specific to the legal field. The enactment of the Code generated a debate upon the means it which it addresses the notion of family. It is a notion regarded today as on a path of decline, due to the profound socio-economic changes, that have caused a series of processes that have recently been intensified: individualism, divorces and abandonment of the perspective of marriage, rise of the rate of abortions, the decline of the status of the children and of the teenagers.

Our research stretched out that, despite these phenomena, the new codes maintain their incorporation of the traditional concepts. More so, the spread of NRT, of insemination, of surrogate mothers, of demands for rights initiated by the homosexuals and the struggle for their awareness have also contributed to the socio-cultural shift that we are discussing. The author of the previously showcased pessimistic conclusions used the concept of family in its classic sense in his study ${ }^{57}$, as long as any other meaning remains in an area which excludes the possibility to procreate. He finally makes a compelling case for the family's reconstruction, just as the Romanian Orthodox Church actively seeks the return to the values of the "traditional family" 58 , in which contraception and abortion are not regarded well, and the notion of family cannot mean anything other than what is currently defined by the Romanian New Civil Code in its art. 259 par. 1 . These politics are a reaction to the process of secularization that was witnessed at a European level during the past two hundred years, following which the bans on marriage have been lifted, abortions have been legalized, adoption was allowed and, finally, starting with the seventh decade of the XXth century, artificial contraception has spread ${ }^{59}$.

However, not every one of these factors have been present in the Romanian societal space. On the other hand, the personal option of any citizen may vary from atheism to bigotry. It is important to take note that the recent unfolding of events (the idea circulated in the fall of the year 2016 to organize a referendum for the "traditional" redefinition of the family in the Romanian Constitution) transpose the sufficient viability of the Christian-orthodox ideas in the mental and imaginary of the Romanian people. We have already analyzed the causes of this viability, previously in the text before, and the scholarly literature highlights the fact that Romania currently has one of the highest degrees of population religious adherence in the entire European Union ${ }^{60}$. The fact that these ideas end up being demagogically exploited by one or another does not change the conclusion of their existence and vitality: if they would not exist, there would be nothing to exploit. 
Is the legal successional order influenced by religious concepts? The answer is affirmative. We have seen over the course of this presentation how (e.g.) the dowry practices undoubtedly have religious roots. However, these practices, along with the religious precepts find themselves secularized in the practices and moral codes of many, because starting with the XIXth century all of the aspects pertaining to family life have been secularized.

15. Let us try to present a summary of the European civilization's space ${ }^{61}$. By doing so, we observe that up until the XVIIIth century the traditional family pattern was based on a marital link based on the family patrimony and indifferent as to affection. The period between the end of the XVIIIth century and middle of the XXth century saw the blossoming of a family romantically based on mutual affection, division of labor and public education of children. The decades following 1960 however completely shifted the paradigm:

"This family joins for a relative amount of time two individuals seeking intimate relations or sexual fulfillment. The grant of authority becomes more and more problematic as the numbers of divorces, breakups and conjugal restructuring cases increase.

Without a paternal backbone, without a symbolic law, the mutilated family of the postindustrial societies would be perverted in its very function as the basic societal cell. It would succumb to hedonism, to the "no limits" ideology. Mono-parental, homo-parental, recomposed, deconstructed, artificially sustained, attacked from the inside by the pretended neglectors of the difference between the sexes, it would not be capable of displaying its own values anymore. [...]

Our age generates a profound confusion as far as the family is concerned. The powers of sex seem to be more extended than ever, generating a specific anguish and disorder, linked to the fear caused by the disappearance of the difference between the genders, having as its final perspective the dissolution of the family. In the modern age, family was more and more desacralized and has stopped being conceptualized as the paradigm of a divine or State-originated vigor, though remaining, paradoxically, the strongest human institution present in the society." ${ }^{\prime 62}$

We thus find ourselves in a transitory stage, in which a clear direction of the evolution of the family concept cannot be discerned. The heightening of the novel elements becomes linked with the revaluation of the traditional elements:

„The postmodern family does not designate, according to this perspective, a new model of family and neither the next stage in the evolution of the family concept, but one in which the very idea of evolution has no standing." ${ }^{\prime 63}$

Our final opinion is that the legal successional order of the New Civil Code does not completely reflect every sociologic reality present in the Romanian society. Moreover, it is a regulation that turns more towards the past, its provisions not being sufficiently permissive in order to host future legal acceptances of some other family configurations ${ }^{64}$.

We believe however that, from the legislative technique standpoint, this creates a good as well as a less good part.

The good part is that it offers the possibility of fixing its lacking provisions by creating regimes parallel to marriage through laws that complete the Civil Code. Our lawmaker has the possibility to create - if and when it will see fit - a successional legal framework for the civil 
partnership (be it heterosexual or homosexual in nature) and for the mono-parental family. Sociological research show that, even though consensual unions (cohabitation) have gained increased incidence following the year 1960, alternative types of families of all kinds are still reduced in numbers ${ }^{65}$. Still in the ambit of the good part is the acknowledgment that, in Romania, the incidence of marriage - even as low as it stands - is among the highest in the European territory ${ }^{66}$. In addition, consensual unions are not fundamentally different as an option from marriage: these represent a pragmatic option created following the model of the married family, to which their great majority declare to tend to ${ }^{67}$.

The less good part is that such a way of action is contrary to the very purpose of the codification process. A new code was necessary (both in our and in other countries as well) also due to the fact that one of the phenomena that accompanies its aging is the plurality of normative acts which accumulate around it over time. A plethora of interpretative laws, completion or/and modification laws, republishing laws, renumbering laws, petite provisions lost in normative acts which have more or less to do with the code. These regulations end up as parasites to the code, which according to the specific means in which the European system of continental law (of Roman-Germanic origin) is supposed to function should be an abridged easy synthesis and the central source of regulation for the field of law that it regulates. In addition, the efforts to recode were initiated in order to refresh its content in accordance with modern time tendencies and to order its structure by absorbing the parasite-type legislation, which became more voluminous than the code itself. It would thus have been optimal to proceed with increased vision, by creating within the code a legal framework for the family, which would be far more permissive in case of future shifts ${ }^{68}$. A reputed Romanian sociologist wrote to this end:

"Let us stop the highlighting of the crucial importance of the laws, regulations and State policies not just in relation to the quality of the life of the monogamous family, but also in its genesis and means of functioning. [...] In Sweden, for example, after the modification of the requirements for state welfare for the single mother caring for a child in the ' 80 s, by having her monetary payment diminished, the number of children born outside marriage has dropped significantly. Before these modifications, many women, even though they had a stable partner, preferred declaring themselves unmarried." 69

An additional issue needs to be looked at on top of the undesirable consequences of the manner in which the Romanian New Civil Code was drafted. The special regulation outside of the realm of the Code of other types and family compositions will complicate the legal devolution of the succession: legal differences will arise between the heirs from the standpoint of personal affinities, which will in turn negatively affect the simplicity and predictability of the successional regime. A great array of particular solutions external to the Code will appear and will have the possibility if conflicting with the imperative of the equality of same-category heirs. These are born out of the principles set forth in Europe by the French Revolution of 1789 and integrated in the Napoleonic Code, the fundamental source of both the Old and the New Romanian Civil Codes ${ }^{70}$.

16. As far as the surviving spouse is concerned, the legislative technique solution used in the Québec codification of 1994 appears to us more adequate than the Romanian 
one of 2009, just like the Canadian solution regarding the composition of the classes of heirs $^{71}$. The Romanian Civil Code uses the regulation technique borrowed by our lawmaker in 1944 from the German Code, which is also used in the Swiss one ${ }^{72}$. It is true that the spouse, now primordial actor of the legal succession, was brought to compete with each class of blood relatives; but he was placed by the Code as separate from these, which remained intact in their criteria of cognac composition. The Swiss authors do not even realize the fact that they did not move the reform all the way from a technical standpoint, by affirming that the absorption of the spouse in a legal devolution, which was freed from the blood relation criteria, would have been realized (sic! $)^{73}$. The charge is backed by the Québec Civil Code, which integrated them effectively by creating new types of heir classes: art. 666-669 CcQ discuss the order (class) of the surviving spouse and of the descendants, art. 670-676 CcQ deals with the successional devolution in the class of the surviving spouse and of the privileged ascendants or collaterals.

Why is the aspect undergoing discussion important? We have analyzed in detail the controversies that appeared in the Romanian Law regarding the reserve calculation for the spouse when competing against both categories of the second class. They would all have been eliminated if the Québec Civil Code solution had adopted: in the presence of the surviving spouse, only the parents have the right to inherit (art. $672 \mathrm{CcQ}$ ). The privileged collaterals have vocation either in the absence of the privileged ascendants (art. $673 \mathrm{CcQ}$ ) either when they find themselves competing against the latter, but in the absence of the spouse (art. $674 \mathrm{CcQ})^{74}$. Moreover, the vocation in collateral line within the second class stops at the third degree (art. 670 par. 2 CcQ), the brother great-grandchildren being moved to the third class - an independent category which will compete distinctly against the rest of the ordinary ascendants and collaterals (art. $678 \mathrm{CcQ})^{75}$.

In the Romanian New Civil Code, the hesitations to the establishment process for the reserve have been resolved though by adopting the calculation framework employed by Professor Deak. E.g., even if a universal will provision completely disinherits the privileged collaterals, the reserve of the surviving spouse and of the privileged ascendants is determined by the measure of half of the quota that would be allotted to them in the ab intestato inheritance- where they would have competed against the brothers and the sisters. However, the technical solution of the Québec lawmaker appears to us to be more in line with the current tendencies regarding the concept of family. The heir classes have been rearranged in such a manner that no trace of the old one between blood relative heirs and irregular heirs subsists: the surviving spouse is integrated in a successional order in which everyone is considered to simply be a legal heir. When he has the vocation to compete for the heritage distribution, he eliminates the ordinary ascendants and collaterals ${ }^{76}$, which were regrouped in a unique third class - solutions which accurately express the radical becoming nuclear phenomenon of the contemporary family. The same sociological tendency finds its expression as well in moving the privileged collaterals of the fourth degree within the final class, which consolidates the legal vocation of the surviving spouse to an even greater extent. 
The final part of the conclusion presented above also applies to the Romanian New Civil Code, if we are to analyze the case law presented in the section dedicated to the successional rights of the surviving spouse. As a consequence, we believe that, even though the decision of our civil lawmaker is a primarily correct one (his successional vocation increased), it remains subject to criticism in its concrete sizing aspect.

17. The specific question, which arises in this point of the discussion, would be the following: what nature should the rights granted as such have? As was showcased now almost one century ago,

"I...] we believe that the fact that the surviving spouse benefits with preference of a part of the goods, or even of their totality, will profit both the private as well as the national economies. [...] the dispersion of the goods in the hands of the great number of distant blood relatives, an economic disadvantage accentuated rightfully by the competent ones, is dismissed or lessened by the just preference granted to the surviving spouse to such greater extent as he would compete with more distant blood relatives." ${ }^{\prime 77}$

Following this general announcement, the reputed Cluj-based Professor reached a specific solution, which appears to us as more equitable than that of the current Code. When competing against the common children, if the spouses were married in accordance with the community regime, he proposed that they be granted one-third in usufruct. He/she he would keep this right even in the case of remarriage, which could be transformed upon the request of the children into life annuity; if they were married in accordance with the separation regime, then they would receive at least one third in full ownership ${ }^{78}$. When competing against the children of the deceased from a different communion, he proposed either one third in usufruct - with the possibility to request the conversion for the spouse as well, either in full ownership (the Callimachus Code solution). Negrea opted for the first choice. He then grants $1 / 2$ in competition against all the other blood relatives of the deceased, eliminating other ascendants than the grandparents and the ordinary collaterals. He also proposes the grant of a reserve, fundamental on the fact that otherwise the right of the spouse would be an illusory one ${ }^{79}$.

Alexandru Cerban revisits Negrea's motivation and solution in time, in his criticism of the provisions regulating the matter at hand contained by the Charles II Civil Code. Moreover, the prestigious Bucharest-based Professor noted:

"The usufruct right attributed to the surviving spouse, which is calculated so that in neither case it would be inferior to a quarter of the successional base value, is adequate to represent an insurance of the financial standing of the surviving spouse. It is allowing the latter to continue enjoying the same lifestyle that he led during marriage and at the same time is advantageous due to the fact that it maintains the deceased's goods in his family. However, this result would not be achieved in the case of a full ownership grant to the benefit of the surviving spouse and when the descendants that he would come up to compete against would originate in another marriage contracted by the deceased. The successional right to usufruct granted to the surviving spouse also holds the advantage that it is susceptible to reduction when the spouse moves on to the second marriage." ${ }^{\prime 80}$ 
We have though discovered how the patron of Camil Negrea's 1924 study, The National Council of Romanian Women, concluded to the opposite:

"The successional rights of the widow and even of the man must have preference to those of the children; they must enjoy in respect to the latter not a portion in usufruct, but in full ownership (our highlighting - MDB) that is no smaller than one third. The mobile worth which amounts to the household must be granted exclusively to the benefit of the surviving spouse, in order to avoid the sad spectacle of these times, when the widow can be cast away by other heirs from her very own home." 81

In 1931, by restating his own Bachelor Thesis conclusions defended in the year 1903, Lawyer Popescu Copuz advocated:

„Let the surviving spouse thus be granted half of the estate of the pre-deceased, as privileged personal rights, to the benefit of both the woman and the man, when competing against the collaterals. When competing against legitimate descendants, a part of either $1 / 3$ or $1 / 4$ in full ownership, in accordance with the number of the heirs, without it being possible that this right can be modified through will provisions.

Let however requirements be placed upon the surviving spouse, morality, both in respect to the past as well as to the future. Proven adultery and notorious infidelity, as well as the overall behavior exhibitive of debauchery on the part of the surviving spouse, that would tarnish the memory of the deceased, all amount to the consequence of removing the right to inherit." 82

A Belgian author considered that the vast variety and the heterogeneous nature of the family configurations, the conditional nature of the conjugal tie, the various patrimonial ties interweaved between the spouses (those of another nature than successional expectations) have to be taken into account. They all lead to the conclusion that an alimony-type of personal right and a matrimonial-type right to the conjugal home would represent the optimal solution. ${ }^{83}$

18. In order to be able to decide, we must consider the specific typology of our nowadays fellow. He/she began life on his own as quickly as possible. He/she is „in a relationship" (in the Facebook terminology) but more and more frequently unmarried or divorced (sometimes remarried and having (a) child(-ren) from the previous engagement). $\mathrm{He} /$ she is still more and more frequently being childless or having one child (maximum two $)^{84}$ and lives in a society characterized by ", a discontinuity in the values' system, which affects the stability and leads to difficulty in communication or understanding between the members of the family, promoting a state of uncertainty manifested in the interactions between generations ${ }^{\prime \prime 5}$. By taking into account the permanent increase in the life expectancy and geographic mobility of the family members ${ }^{86}$, we reach a conclusion. The underlying decision reached by the Romanian lawmaker in 2009 to increase the standing of the surviving spouse in the legal successional devolution to the disadvantage of the blood relatives is in line with the evolution of the concept of family. We view it at the same time as being in line with the tradition of the Romanian Ancien Droit, both with customary and the codified law. It is in line with our scholarly research's and practice's constant objective 
following the 1 December 1865 to ensure as much financial comfort for the surviving spouse - enacted into law on the 10 June 1944. It finds itself at the same time in line with the comparative law evolutions ${ }^{87}$.

What we do not agree with is the specific manner in which it resolved it: neither as far as the nature of the rights aspect was resolved, nor - and most of all - as far as the tendency to reduce the grant of successional vocation only to the benefit of the married partner is concerned. As the late French Professor Pierre Catala demonstrated, the life communion with the deceased weaves a series of financial ties, other than the simple successional expectancy ${ }^{88}$. The majority of the Romanian citizens are married under the common legal regime of legal community (art. 312 and 329 Civ.C.). Most of the successions in Romania are comprised of a home and a car that were bought together during the marriage; to the extent to which they are declared at the succession, they are augmented by the family's household goods, some jewelry and possibly some sums of money residing in bank deposits ${ }^{89}$. The death of one of the spouses generates the liquidation of the community, which - regularly - directs half of the couple's goods to the surviving spouse $e^{90}$. To this half a successional quota is added, because the Code allows him to compete against any other heir, be it legal or instituted by means of will provisions (art. 970, 971 and 1087 Civ.C.). He will thus gain the majority stake in the most important good of the successional mass (the home), which he will receive in kind in the division process. To these rights there are other potential additions: the existence of various pension schemes, legal or voluntary, life insurance rights and other precaution-type formulas; accounts held in common; manual gifts, indirect and unobserved donations etc. By also taking into account the increasing level of life expectancy, combined with the process of population aging, manifested in Romania following $1990^{91}$, the surviving spouse is a rather old person and is threatened by poverty in an inversely proportional degree relative to his education level. The State represents his most important source of income, while the relatives from the extended family and the friends intervene more on the side of providing care and emotional comfort ${ }^{92}$. All these aspects are not necessarily taken into consideration by the Romanian successional law, due to the fact that the return to a market economy and a free society are events that have taken place too recently in order for those who have studied to benefit financially from the change and to have reached the time of death. Thus in reality we have to deal with a complex set of circumstances that, specifically, can shift the surviving spouse from the standing of most well off to that of the worst standing out of the legal heirs ${ }^{93}$.

19. The solution that we advance herein presupposes several aspects.

In 2003, when we were taking part in the drafting process of the Civil Code, we compiled a IInd Title named „The legal succession" in which, in order not to brutally break the tie with the case law stemming from the previous decades, we combined the regulating technique of art. 1 Statute 319/1944 with the modern one of the Québec Civil Code of 1994. In this way, we considered we would prepare for the criticisms raised in respect to Statute $319 / 1944$ as far as the manner in which its art. 1 and 2 were drafted was concerned. We augmented the legal quotas of the surviving spouse, following the model of the Romanian 
Civil Code project drafted by Mihail Eliescu in 1971 and, partially, that of the French Reform Law of the 3rd of December 2001.

By bringing the spouse to the front of the successional order, we intended to legally acknowledge the reality of the paradigm shift over his successional standing. We noticed even at that time how the Québec Civil Code $^{94}$ expresses this fact by making use of the legislative technique detailed above: in the chapter called "Of the order of devolution of the succession" (art. 666-687 CcQ) regulates the rights of the surviving spouse within each class of heirs. This seemed to us as the most appropriate, as long as the surviving spouse cannot be regarded as being a distinct category of heritage, but must be called to compete against the components of the class alongside which he is effectively called to the successional division with. The research process that we have undertaken has allowed us to acknowledge that - in the conscience of the Romanian society of the end of the XXth century - he is called alongside blood relatives from each class exactly in the same manner in which, inside the second class, the parents of the deceased compete against his privileged collaterals. Such a legislative technique is able to better illustrate his absorption within the Code's legal successional order, than if he is left - as the Romanian Civil Code of 2009 currently states- to stand alone in a section that is separated from the blood relatives. The Romanian reform of 1944 was a gate left wide open for the surviving spouse to become a legal heir alike the others, after the fact that the not-enacted Civil Code of 1940 made him a prime degree heir, but did not dare to place him in the same section as the blood relatives.

We proposed that the surviving spouse would eliminate the ordinary ascendants and collaterals from the successional order - a solution that was common to the Eliescu project, the Québec Code and the French Law of the 3rd of December 2001. As far as the competition with the descendants is concerned, we proposed the reactivation of the successional rights to usufruct, following the French reform model ${ }^{95}$ :

Art. 10 - The surviving spouse and the descendants. When competing alongside the descendants, the surviving spouse has the right to choose between a quarter in full ownership and the usufruct of the entirety. In the absence of the spouse, the heritage is offered to the descendants. (art. 669 c.c.; 843 par. 1 c.c. 1971; 757 and 735 fr.; 666 and 667 CcQ; par. 1 let. of Statute 319/1944)

Art. 11 - Until the exercise of the option between the full ownership and the usufruct, the respective rights of the surviving spouse are non-transferable. (art. 758-1 fr.)

Art. 12 - The choice between the full ownership and the usufruct can be demonstrated through any means of proof.

Any heir may address a written invitation to the surviving spouse in order for the latter to exercise his option. The lack of a written response over the course of a three month term presumes the choice of the usufruct.

The surviving spouse is considered to have opted for the usufruct if he deceases prior to exercising his right to choice. (art. 758-2 - 758-4 fr.)

Art. 13 - When competing alongside the descendants, the surviving spouse does not have the usufruct option in any of the following cases: 
a) if at the time that the succession was open he did not reach 40 years of age and at that time at least 10 years have not passed since the marriage took place;

b) if at the time that the succession was open any of the former spouses or both together registered a request for divorce;

c) against the descendants belonging only to the deceased. (art. $757 \mathrm{fr}$; IV.3.23 L.Car.)

Art. 14 - Any right of usufruct belonging to the surviving spouse over the successional goods, regardless of whether stemming from the law, will or donation of future goods, offers the option to conversion in lifetime annuity, at the request of any pure proprietor or of the surviving spouse himself.

The option to convert is not susceptible to be renounced to by will of its beneficiaries or to be eliminated by the will of de cuius. (art. 759 şi 759-1 fr.)

Art. 15 - In the absence of the parties' agreement, the request to convert is subject to analysis of a court of law, and can be introduced up to the date that the final division has taken place. The judge establishes the value of the annuity, the warranties which must be provided by the debtor heirs, as well as the adequate means of indexing.

The conversion of the usufruct of the home, which he occupied as his main residence, and of its furniture cannot be admitted without the approval of the surviving spouse. (art. $760 \mathrm{fr}$.)

Art. 16 - The conversion of the usufruct to a capital can only be exercised through an agreement between the heirs and the surviving spouse. (art. $761 \mathrm{fr}$.)

Art. 17 - The conversion of the usufruct is included in the division process. (art. $762 \mathrm{fr}$.)

The spouse's rights were supposed to become full ownership ones in case of competition alongside the other classes of heirs. The usufruct solution was however regarded with reticence by the other members of the Commission ${ }^{96}$, and it became apparent to us that a common solution from the time before 1865 had been forgotten and now drew the presupposition that will become too burdensome. The solution was disputable in and of itself $f^{97}$, being as challenging as the very decision on the legal nature of the type of successional right that should be granted to the surviving spouse. An author very justly acknowledged the fact that "the issue of the legal nature of the successional reserve is one of the most controversial in our law of successions ${ }^{\prime \prime 98}$ !

A right to full ownership implies the disadvantage of the transfer incurring a double taxation (once at the time of the death of de cuius and the second time at the death of the surviving wife), until it reaches the patrimony of the descendants of the respective couple. A right to usufruct has the advantage of not altering the lifestyle of its beneficiary, while a quota in full ownership may not offer sufficient income to this extent ${ }^{99}$. Moreover, it could represent a solution for the recomposed families in which the spouse competes with descendants of the deceased from another marriage or affair; case law reveals that such couples often avoid marriage, in order not to involve the new partner in the successional rights of the descendants from the first marriage of de cuius. But the usufructuary must conform to the restrictions imposed upon him by the Civil Code and may end up in a state of cohabitation with the soleproprietor descendants that are not necessarily favorable to him. Therefore, he is not sufficiently interested in caring for maintaining the good ${ }^{100}$ and will not be able to efficiently 
set it up as a guarantee in order to facilitate access to loans. Moreover, in the XIXth century practice, the poor widow's usufruct established by art. 684 c.c. was often times converted to money, conversion which did not always prove to be facile ${ }^{101}$ (a difficulty also present today in countries like Belgium or France, which use the solution of the usufruct ${ }^{102}$ ).

20. As a consequence, we have renounced the introduction of the usufruct and the second version was presented like this:

\section{Chap II - Heirs}

Sect. I - The inheritance rights of the surviving spouse

Art. 13 - The surviving spouse. The surviving spouse has the right to inherit if at the date of the opening of the succession there does not exist a definitive divorce decision. (art. 732 fr.; art. 961 C.Cal.)

The surviving spouse is called to compete in the inheritance procedures alongside the descendants, the privileged ascendants and the privileged collaterals. In the absence of these categories, he has the right to the full worth of the deceased. (art. 846 par. 1 and 3 c.c.1971; 756 fr.; 583 it.)

Art. 14 - The right of home usage. The surviving spouse that has no other own home will benefit for two years from the date that the succession became open, additionally from the inheritance rights contained in the current chapter, by a right of use pertaining to the home in which he lived, if this is part of the succession, as well as to the furniture, contained in the succession and located in the respective home. (art. 840 c.c.1940; 846 par. 2 thesis 1 c.c.1971; 757 and 735 fr.; 666 and 667 CcQ; art. 1 let. a-c Statute 319/1944)

If his presence in the home was insured through a rent contract, the money equivalent of the rent values will be reimbursed to him from the succession, on the basis of their payment. (art. $757 \mathrm{fr}$.)

The other heirs have the right to procure an equivalent housing facility for the surviving spouse. The disputes arising over the housing procurement process will be decided upon by the court of law charged with the division of the successional mass, which will decide urgently in the council chamber.

The rights contained in the current article are reputed as direct consequences of marriage and not as successional rights. These cease in case the surviving spouse remarries before the execution of the termination of the state of severalty.

The current article is of a public order nature.

Sect. II - On the concurrence between the surviving spouse and the first class of heirs

Art. 15 - First class. The descendant's straight descending line relatives are the first ones entitled to succeed him.

The vocation of the descendants reaches out to infinity, regardless of whether they originated from marriage or from outside marriage. (art. 763 fr.) 
Art. 16 - The surviving spouse and the descendants. In a concurrence with the descendants, the surviving spouse has the right to a quota of a child, but no less than a quarter of the inheritance. In the absence of the spouse, the inheritance belongs to the descendants.

The before-mentioned rights of the surviving spouse are reduced in half,

a) if at the time that the succession was open he did not reach 40 years of age and at that time at least 10 years have not passed since the marriage took place;

b) when the concurrence occurs alongside the descendants belonging only to the deceased. (art. 669 c.c.; art. 825 c.c.1940)

Sect. III - On the concurrence between the surviving spouse and the second class of heirs

Art. 17 - The second class. The privileged ascendants are the father and the mother of the deceased. (art. 840 c.c.1940; art. 846 par. 2 thesis 1 c.c.1971; 757 and 735 fr.; 666 and 667 CcQ; art. 1 let. a Statute 319/1944)

The privileged collaterals are the brothers and sisters of the deceased, as well as the first degree descendants thereof.

Art. 18 - The surviving spouse and the second class. In concurrence with the heirs of the second class or with only some of them, the surviving spouse has the right to half of the inheritance.

In the absence of the descendants and the surviving spouse, the parents and privileged collaterals each receive half of the inheritance. In concurrence with a single parent, the latter receive three quarters.

In the absence of the descendants, the surviving spouse and the privileged collaterals, the inheritance is allotted to the parents. In the absence of the descendants, the surviving spouse and privileged ascendants, the inheritance is allotted to the privileged collaterals. (art. $670 \mathrm{CcQ}$ )

Sect. IV - On the third class of heirs

Art. 19 - The third class. The ordinary ascendants are the straight ascending line relatives of the deceased, except for his mother and father. In the category of the ordinary collaterals belong all the collateral relatives of the deceased, except for those belonging to the second class of heirs. (art. 673 c.c.; 829 c.c.1940; 738 fr.)

The ordinary ascendants and collaterals are called to the inheritance only in the absence of the surviving spouse and of the heirs belonging to the first two classes. (art. 671 and 672 c.c.; 674 par. 2 (cQ)

Art. 20 - The ordinary ascendants and collaterals. If among the ordinary collaterals there are descendants of the privileged collaterals, these receive half of the inheritance; the other half is divided between the ascendants and the other collaterals.

In the absence of the descendants of the privileged collaterals, the entire inheritance is transmitted to the ascendants and to the other collaterals - and vice versa.

Art. 21 - The line division. Within the ambit of one line, the division of the inheritance between grandparents and uncles, aunts, as well as their descendants is carried out similarly to the rules applicable to the devolution within the second class. (art. $677 \mathrm{CcQ}$ ) 
In the absence of grandparents, the uncles, aunts and their descendants eliminate the other ascendants from the inheritance, regardless of whether they find themselves pertaining to the same line or not. (art. $678 \mathrm{CcQ}$ )

Art. 22 - The alimony of the ordinary ascendants. During one year from the death of their descendant, the ordinary ascendants eliminated by the surviving spouse may request, if they are in need, an alimony-type of personal right over the inheritance. The term may also begin from the moment in which the heirs cease paying the support that they previously supplied to the ascendants.

The alimony is calculated over the entire inheritance and is owed by all the heirs. In case of insufficiency, particular will-instituted heirs will also be held to contribute.

\section{Sect. V - On the available quota}

Art. 23 - The successional reserve. The will grants included by the deceased will not be able to surpass one third of the inheritance, if it is open to the concurrence of the descendants and of the surviving spouse; half, if it is open to the descendants; two thirds, if it is open to the surviving spouse; three quarters, if it is open to the privileged ascendants and to the surviving spouse; four fifths, if it is open to the privileged ascendants.

The part reserved for the before-mentioned heirs will be divided between them in accordance with the legal successional quotas. (art. 758 fr.)

Under the pressure of the other members of the Commission, we had to renounce applying the legislative technique of the Canadian Code.

It is noticeable how we have maintained the surviving spouse's standing among the heir entitled to a reserve, by backtracking to the regulatory technique of the Napoleonic Code, passed on the the Cuza Code (even though the marginal note to art. 23 of the Vth section referred to the reserve). Between 2006 and 2008, the Commission tasked with the drafting of the amendments to the Civil Code of 2004 has even debated over the opportunity of eliminating the successional reserve. The result of the vote which succeeded the debates was equal (seven versus seven), thus it was decided that the reserve be kept. The presumed affection and the economic collaboration towards the establishment of the family's patrimony are fundamental to the legal devolution. The French reform of 3 December 2001 has granted the reserve to the widow/widowed in a prudent manner, only in the absence of the privileged descendants and ascendants, for the Law of 23 November 2006 to continue and eliminate the reserve of the latter ${ }^{103}$. We must take note though of the traditional nature of the reserve of the surviving spouse in the Romanian law; the French solution to the contrary of 2001 was in fact another product of a symmetrically opposite tradition that the future reform of 2006 has carried out to correct ${ }^{104}$.

The third and fourth classes have fused and received among their ranks the Ind degree descendants of the privileged collaterals (fourth degree relatives in respect to the deceased), following the Québec model. We carried out in such a manner, because we considered that the great-grandchild on the brother's side is not closer from an affective and economically collaborative standpoint to the deceased than his grandparents are. The division between the ordinary ascendants and the ordinary collaterals (other than the 
descendants of the privileged collaterals) is carried out though still as in the case of the concurrence between the similar categories from the second class.

21. The final (third) form of the chapter, which interests us from Title II dedicated to the legal succession, handed over to the Ministry of Justice in July 2003, stated as follows:

\section{Cap II - On heirs}

Sect. I- On the surviving spouse

Art. 13 - The surviving spouse. The surviving spouse has the right to inherit if at the date of the opening of the succession there does not exist a definitive divorce decision. (art. 732 fr.; 961 C.Cal.)

The surviving spouse is called to compete in the inheritance procedures alongside the descendants, the privileged ascendants and the privileged collaterals. In the absence of these categories, he has the right to the full worth of the deceased. (art. 846 par. 1 and 3 c.c.1971; 756 fr.; 583 it.; 1 Statute 319/1944)

Art. 14 - The inheritance rights of the surviving spouse. When called to inherit, the surviving spouse has the following rights to the inheritance of the other spouse:

a) a quarter of the inheritance, in concurrence with the descendants of the deceased;

b) half of the inheritance, in concurrence with the heirs from the second class or with only one of them;

c) the entirety of the inheritance, by eliminating the heirs from the third class. (art. 840 c.c.1940; 846 par. 2 thesis I c.c.1971; 757 and 735 fr.; 666 and 667 CcQ; 1let. a-c Statute 319/1944)

The before-mentioned rights of the surviving spouse are reduced in half,

a) if at the time that the succession was open he did not reach 40 years of age and at that time at least 10 years have not passed since the marriage took place;

b) when the concurrence occurs alongside the descendants belonging only to the deceased. (art. 757 fr.)

$[\ldots]$

Sect. II - On the descendants

Art. 17 - The descendants. The descendant's straight descending line relatives are the first ones entitled to succeed him.

The vocation of the descendants reaches out to infinity, regardless of whether they originated from marriage or from outside marriage. (art. 669 c.c.; 825 c.c.1940)

Art. 18 - The descendants' right to inherit. In the absence of the surviving spouse, the descendants inherit in the order of the proximity of their relative degree, by dividing the inheritance per capita, or, if the case may be, between relative branches. (art. 840 c.c.1940; 846 par. 2 thesis I c.c.1971; 757 and 735 fr.; 666 and 667 CcQ)

$[\ldots]$

Sect. III - On the privileged ascendants and on the privileged collaterals

Art. 19 - The privileged ascendants and the privileged collaterals. The privileged ascendants are the father and the mother of the deceased. 
The privileged collaterals are the brothers and sisters of the deceased, as well as the first-degree descendants thereof. (art. $670 \mathrm{CcQ}$ )

Art. 20 - The rights of the privileged ascendants and collaterals to inherit. In the absence of the descendants and the surviving spouse, the parents and the privileged collaterals each receive half of the inheritance. In concurrence with a single parent, the latter are entitled to three quarters. (art. 673 c.c.; 829 c.c.1940; 738 fr.)

In the absence of the descendants, the surviving spouse and the privileged collaterals, the inheritance is allotted to the parents. In the absence of the descendants, the surviving spouse and privileged ascendants, the inheritance is allotted to the privileged collaterals. (art. 671 and 672 c.c.; 674 par. 2 (CQ)

$[\ldots]$

Sect. IV - On the ordinary ascendants and ordinary collaterals

Art. 21 - The ordinary ascendants and ordinary collaterals. The ordinary ascendants are the straight ascending line relatives of the deceased, except for his mother and father. In the category of the ordinary collaterals belong all the collateral relatives of the deceased, except for those belonging to the second class of heirs.

Art. 22 - The rights to inherit of the ordinary ascendants and collaterals. The ordinary ascendants and collaterals are called to the inheritance only in the absence of the surviving spouse and of the heirs belonging to the first two classes. (art. $677 \mathrm{CcQ}$ )

If among the ordinary collaterals there are descendants of the privileged collaterals, these receive half of the inheritance; the other half is divided between the ascendants and the other collaterals. (art. $678 \mathrm{CcQ}$ )

In the absence of the descendants of the privileged collaterals, the entire inheritance is transmitted to the ascendants and to the other collaterals - and vice versa.

Art. 23 - The line division. Within the ambit of one line, the division of the inheritance between grandparents and uncles, aunts, as well as their descendants is carried out similarly to the rules applicable to the devolution within the second class.

In the absence of grandparents, the uncles, aunts and their descendants eliminate the other ascendants from the inheritance, regardless of whether they find themselves pertaining to the same line or not.

Art. 24 - The alimony of the ordinary ascendants. During one year from the death of their descendant, the ordinary ascendants eliminated by the surviving spouse may request, if they are in need, an alimony-type of personal right over the inheritance. The term may also begin from the moment in which the heirs cease paying the support that they previously supplied to the ascendants.

The alimony is calculated over the entire inheritance and is owed by all the heirs. In case of insufficiency, particular will-instituted heirs will also be held to contribute. (art. 758 fr.)

We have prescribed a differentiated successional quota for the surviving spouse in each of the three versions, according to his specific age and to the duration of the marriage, as well as according to whether he is in concurrence with descendants that belong only to the 
deceased. The solution was inspired by art. 841 par. 1 c.c.1940 and sought the establishment of a balance between persistency as part of a characterized family life (long-term collaboration in a single marriage, with descendants belonging only to it) and the concurrent rights ${ }^{105}$. In addition, within the last version the right to habitation and that over the mobile property belonging to the household have been restored, in approximately the same manner as it was regulated in 1944 - the reason for which we did not restate art. 15 and 16.

This final version was an articulated synthesis of all the proposals and tendencies towards reform in the matter in Romania, linked to the most recent reforms offered by the comparative law at that time. A result of stormy and fruitful debates within the Commission, it gathered the unanimous approval of its members. It did not manage to stand facing the post factum intervention over the provisions, which took place in September 2003 at the hand of a non-specialist relative to the field of the law of successions.

We are of the opinion that the solutions of the final version expressed in the legislative technique of Canadian inspiration of the first version would have represented the optimal regulation of the Romanian successional devolution for the 2004 moment. Matters have however evolved from then on, making it impossible to consider now family without having in mind its alternative facets about which we have discussed over the course of our research endeavor. These forms existed a decade ago as well, but we believe the Romanian society was not ready to acknowledge them.

22. The current research makes us believe in the need to regulate a civil partnership that, in the current state of the Romanian society, should not however have successional consequences $^{106}$. The regulation could be enacted by means of special statute and its introduction within the ambit of the Civil Code having the potential to destabilize the latter's balance. Moreover, the letter and the prestige of the Code would thus remain untarnished, regardless of whether future evolutions would diminish or would augment the interest for the civil partnership. We consider our solution as being the most compatible with the conclusion according to which the array of family types of the postmodern era has not changed the European predominance of the classical configuration family ${ }^{107}$.

As far as the partnership is concerned, it would represent a gateway for future evolutions, allowing the partners - whose gender should not be specified de plano within the text - to create a patrimonial regime of cohabitation by choosing one of the matrimonial regimes provided by the Code. The limitation is necessary, otherwise the civil partnership would become a preferred means of eluding the numerus clausus of the regimes prescribed by the Code, in order to enable the creation of any type of regime relative to property which would in turn further diminish the number of classic-type marriages.

As far as the legal successional order is concerned, we consider that the reserve of the privileged ascendants must be eliminated, being at the very most (and only to a partial extent) compensated with an alimony type of personal right. The goods must be passed on in descendent manner between the generations of the current family, where the specific relationships and the large age gaps between these do not justify (the way they used to in the XIXth or in the first half of the XXth centuries) the opportunity of their return to the previous generation any more. 
23. The focal point of the discussion remains the competitive successional couple comprised of the surviving spouse and the descendants of the deceased ${ }^{108}$. By overviewing the evolutions that we examined over the course of our research, a few conclusions may be drawn. The sociological evolutions of the family represent the source of shifting the center of gravity of the legal successional devolution towards the previously mentioned categories. Within the spouse-descendants binomial, the balance of forces was variable. The Statutes of 15 March 1906 and 10 July 1943, the Decree of 2 April 1949 and the Family Code of 1 February 1954 have constantly enlarged the ambit of the descendants that are apt to inherit through the integration of the illegitimate children. The Statutes of 21 December 1916, 28 June 1921, 28 June 1923, 1 July 1941 and 10 June 1944 and 17 July 2009 have gradually increased the rights of the surviving spouse, moving him from the end of the heir list to its top. The legislative evolution that we presented confirms the sociological tendencies that, as has been witnessed over the course of our research, have moved the affectionate and pecuniary center of gravity towards the life partner. He is today a legal heir preeminent to any class, benefits from a successional reserve, is held for and has a right to the report of the liberalities, and is a factual possessor of the successional goods.

By drawing the line, we can observe how - despite the alternation of the legislative measures in favor of the two categories undergoing analysis - the ultimate winner was the surviving spouse. The conclusion was also verified in the previous chapters through the comparative law analysis that we have constructed.

24. The members of the successional "couple" that we denominated above must be seen in their concurrence with the ever-greater wish for attaining the freedom to freely enjoy one's own property.

We are of the opinion that the $a b$ intestato balance in this "couple" is well organized by the New Civil Code (both from the standpoint of the rights, as well as its extent). As shown in the Italian scholarly literature,

„In the modern society, with an ever-increasingly articulate structure and an everhigher degree of social mobility, the number of great personal patrimonies has shrunk forcefully and, at the same time, the creation of medium and small patrimonies has developed a great deal, as a consequence of the increased development of the middle classes. In our age it is difficult for the surviving spouse to live off only through the income provided by a quota of these patrimonies, which rarely include highly-profitable assets; the spouse has more and more of a need for capital, the legislative choice of granting him a quota of the patrimony in full ownership thus being justified."109

The issue is much more delicate as far as the establishment of the reserve is concerned. An abstract quota reserve out of the successional mass (as it now stands), regardless of whether it is in usufruct or in full ownership form, may be unreliable. Indeed, if we are to refer only to the surviving wife, she may thus be exposed to the drawing and auction that are part of the division process, and she could lose her life-frame without receiving a substantial equivalent in terms of resources in exchange. A reserve in usufruct 
moreover expresses an alimony type of basis of the obligation to pass something on that the predeceased spouse owes to the surviving spouse. Still, the Romanian successional law, on 10 June 1944 assumed the idea that the spouse is no longer a foreigner in a family that is centered on blood kinship; he is the co-founder of the family and co-builder of its patrimony ${ }^{110}$. A reserve in full ownership imputed over the reserve pertaining to the descendants would be too modest and inadequate from the perspective of the logic of our successional system. A reserve in full ownership imputed over the available quota (as is the one instituted in 1944 and integrated in the New Civil Code) did not long after become faced with the principle-generated hostility of any liberal economic regime, whose constant reflex is to increase the freedom of disposition ${ }^{111}$.

The debate carried within the Commission tasked with amending the Civil Code of 2004 regarding the potential elimination of this institution amounts to a strong proof in this sense. Other proof is supplied by the practice of the notaries public, where a diminished number of wills and donations of immovable has been witnessed. The latter ended up being avoided due to the fact that the banking institutions are cautious in accepting the underlying guarantee of immovable goods acquired through donation for the loan facilities that they grant. Their attitude is due to the fact that they fear the reduction which may be pursued by the reserve heirs of the donor in the case of the latter's death persists. The same case law reveals subterfuges utilized in the past decades by the citizens in order to circumvent the reserve:

- donations disguised as onerous acts (sales, contracts of support, transmissions with the creation of usufruct or combinations of these operations);

- sales to a reserve heir followed shortly by the creation of a usufruct (or of a contract of support) in favor of the old seller, in the goal of circumventing the gratuity presumption of art. 845 c.c. $=$ art. 1091 par. 4 Civ.C. ${ }^{112}$;

- a mandate to sell handed by de cuius to one of his presumptive reserve heirs, doubled by the occult convention that the executor of the mandate should factually assume the price;

- sales with the occasion of which the buyer presents the notary public the proof of bank placement of the price at the disposal of the seller, followed by the cashing out process and their pre-agreed restitution to the buyer;

- entering a lifelong alimony contract, the alimony sums that are owed in exchange for the immovable being paid out to a bank account. The payment of the installments thus becomes easy to prove - which ensures that the contract is onerous in nature. In fact, the annuity debtor regains possession of the sums that he deposited into an account opened in the annuity creditor's name and associated with a debit card, from an ATM machine, or, directly from the bank by means of a mandate issued by the annuity creditor to the annuity debtor or by one of the latter's interposed representatives;

- ascendants' partitions by means of which a child declares that he received the house, the other that he received a sum of money. In reality, the respective sum never existed;

- fictitious acknowledgments of debt issued by de cuius, followed by payments to those he wishes to favor in respect to the reserve heirs etc. 
In order to find a middle ground, we consider that the current means of establishing the reserve may be maintained ( $1 / 2$ of what would have been received in a legal succession, both for the surviving spouse, as well as for the descendants). But, from the standpoint of the legal nature, a more courageous shift than the one that took place up until now should be made towards the pars bonorum successional reserve conception. It is the conception that currently exists in important Codes such as the German and the Dutch ones (1992) $)^{113}$ - in the direction of which we have seen the French successional law is also heading vigorously, following the reform of 2006. We have proved that this conception was also present in the Cuza Code and was enforced in the Romanian New Civil Code; but our author colleagues do not acknowledge it and continue to affirm that in our country the reserve was and remains a pars hereditatis (sic!). A pars bonorum conception that would contribute to reduced conflicts over prerogatives in respect to the goods, alongside the replacement of the reduction in kind (art. 1097 par. 2 Civ.C.) with that by equivalent ${ }^{114}$. A conception which - a bridge over time - was the one of lex Falcidia, the Roman statute that in the year 40 B.C. set the basis for this fundamental institution of continental European Law appears to us as the proper solution: de cuius freely enjoys disposition over his goods, while the beneficiaries of his liberal will have to pay out the parts corresponding to successional reserves in equivalent to those entitled.

The reserve must thus constitute a personal right over the succession - privileged to the degree of first ranking, as lawyer lon Popescu Copuz proposed in his Bachelor's thesis that he defended in the year 1903. The sizing of the reserves and the identity of the reserve heirs can remain unchanged in respect to the ones currently in place from the New Civil Code, with the exception of the parental reserve - which should be eliminated ${ }^{115}$. This change would better be accompanied by a measure of excluding donations of immovables that are older than twenty years ${ }^{116}$ and those of movables that are minimum ten years old from reduction, as well as the implementation and enforcing of the rule of reduction through equivalent.

Instead of a conclusion to the conclusions:

„Family today bears a great deal of denominations, but [...] what truly matters is, in fact, the interaction between its members; how they support each other, if there is someone to give affection to [...].

Maybe family today is not as iconic as it once was, but it still exists and strives to demonstrate its aliveness through a variety of means. Just as the old models were so have new ones been born, and we must learn how to make room for the latter and how to value them appropriately."117 
LIST OF ABREVIATIONS used in the text and in endnotes:

BNP - Buletinul notarilor publici (Bucharest)

BYU - Brigham Young University Journal of Public Law (Provo, Utah)

C.c. - Romanian civil code of 1864

c.c. 1940 - Romania civil code of 1940

c.c.1971 - Romanian (project) of civil code of 1971

C.Cal. - Calimach Code (Principality of Moldavia, 1816)

CcQ - Civil code of Québec

C.Jud. - Curierul judiciar (Bucharest)

Ch.D. - Cahiers de droit (Sherbrooke)

fr. - French civil code

it. - Italian civil code

JCP-N - Juris-classeur périodique - édition Notariale (Paris)

Jur.Gen. - Jurisprudenţa general (Bucharest)

RRS - Revista română de statistică (Bucharest)

SUBBiur. - Studia Universitatis "Babeş-Bolyai", series lurisprudentia (Cluj-Napoca)

${ }^{1}$ This study contains the final conclusion of the research grant PN-II-ID-PCE-2011-3-0249 (contrat no. 174 of 2011) The relevance of the evolution of family as concept on the legal succession order $-a$ socio-juridical, philosophical and religious investigation.

* Professor, Faculty of Law, UBB Cluj-Napoca; mirceabob@law.ubbcluj.ro.

${ }^{2}$ Law no 319 of 10 June 1944, on the successional rights of the surviving spouse.

${ }^{3}$ M.D. Bob, Probleme de moşteniri în vechiul şi în noul cod civil, Bucharest 2012, pp. 66-67.

${ }^{4}$ Vasilescu, Cât de funcţional este regimul separaţiei între soţi?, în Evoluţia noţiunii de familie şi influenţa acesteia asupra ordinii succesorale legale, M.D. Bob (editor), Bucharest 2013, p. 33 (or the French version: Le poisson mort au vivier: la séparation entre époux, in SUBBiur. (59) 2013.2.25, http://studia.law.ubbcluj.ro/articol/547).

${ }^{5}$ Matrimonial benefit given over and above the surviving spouse's share.

${ }^{6}$ M. Nicolae, Codex iurisi civilis tomul I - Noul Cod civil, ediţie critică, Bucharest 2012, pp. CXIX-CXXII.

${ }^{7}$ Art. 259 par. 1 civ.c.: „Marriage is the freely-consented union between a man and a woman, in accordance with the provisions of the law."[original Romanian wording "Căsătoria este uniunea liber consimţită între un bărbat şi o femeie, încheiată în condiţiile legii."]

${ }^{8}$ I. Gruia, Raport către M.S. Regele, in Codul civil Carol al II-lea. Cuprinzând: 1. TEXTUL INTEGRAL, publicat în M. Of. p. I Nr. 206 din 6 Septembrie 1940; 2. DECRETUL-LEGE PENTRU MODIFICAREA CODULUI CIVIL CAROL al II-lea, cu raportul către M.S. Regele şi referatul către Consiliul de Miniştri, publicate în M. Of. p. I Nr. 200 din 30 August 1940. - Ediţie oficială, Bucharest 1940, p. 638. The main point of the quoted paragraph appears excellent to us, even though its application was derailed by its author in a Nazi perspective.

${ }^{9}$ Its works were published in Bob, Evoluţia..., cit.supra.

${ }^{10}$ We revisit here, in a synthetic manner, the conclusions of B. Lefebvre, Soţul supravieţuitor: creditor, moştenitor sau terţ faţă de succesiune în dreptul din Québec, în Bob, Evoluţia..., cit.supra, pp. 99-120 (versiunea franceză: Le conjoint survivant: creancier, heritier ou etranger a la succession en droit quebecois?, în SUBBiur. (59) 2013.2.72-89, http://studia.law.ubbcluj.ro/articol/550).

${ }^{11}$ Québec (Attorney General) c. A, 2013 CSC 5. This case is known under the fictitious name Lola v. Éric. 
${ }^{12}$ Four out of five Justices were of the opinion that the provisions of the Civil Code are discriminatory in respect to art. 15 of the Charter. Nevertheless, the Chief Justice held the view that the difference of treatment between married couples and cohabitants was justified within a free and democratic society, in accordance with the provision of the Charter's first article. Three Justices would have validated the Civil Code provisions based on article 1 , as far as they were concerned - except for those of art. 585 Q.C.c. regarding alimony.

${ }^{13}$ The Government of Québec named a Committee of experts in order to revise family law. This Committee delivered its Report in June 2015, without any lawmaker response at that time. We will briefly present the proposals at the end of the current Section. For more details, see Comité consultatif sur le droit de la famille, Alain Roy (president), Pour un droit de la famille adapté aux nouvelles réalités conjugales et familiales, Montréal 2015.

${ }^{14}$ In 1981, 8\% of the couples in Québec lived in factual cohabitation status. In this time, the factual cohabitation often represented a precursor stage for marriage. This percentage grew from $19 \%$ in 1991 , to $24 \%$ in 1996, 30\% in 2001, 36\% in 2006 and 38\% in 2011. It represents the evolution of a pattern which is much more prominent in Québec than in other Canadian provinces. Indeed, national statistics reveal that it accounts for $19 \%$ of the factual cohabitant couples living in Canada, when taking into consideration all of the provinces.

${ }^{15}$ For the framing of the family rapports, see: A. Roy [and] V. Lemay, Le contrat conjugal : pour l'amour ou pour la guerre?, Montréal 2009.

${ }^{16}$ Other nine common law provinces acknowledged all the obligations related to the issue of alimony applicable in the case of the factual cohabitants after 2 or 3 years or from the moment they begin to share the parenting of the same child. Four of them grant the division of family property rights and a successional potential to factual cohabitants after 2 or 3 years of cohabitation as well. In this framework, the presence of a common child does not impact the issue at hand.

${ }^{17}$ It is the proposal stemming from the fact that Justice Abella in the matter of Lola. Québec (Attorney General) v. A, 2013 CSC 5, (par. 360).

${ }^{18}$ D. Goubau [and] G. Otis [and] D. Robitaille, La spécificité patrimoniale de l'union de fait : le libre choix et ses dommages collatéraux, in Ch.D. (44) 2003, 1, p. 49.

${ }^{19} \mathrm{C}$. Rogerson [and] R. Thompson, Lignes directrices facultatives en matière de pensions alimentaires pour époux : ébauche d'une proposition, ministère de la Justice, Canada, January 2005, http://canada.justice.gc.ca/fr/dept/pub/spousal/index.html. These guidelines were submitted to the Justice Department by two law professors. They are not mandatory, due to the fact that they are not enacted as part of a law or regulation.

${ }^{20} \mathrm{~J}$. Jarry, Les conjoints de fait au Québec : vers un encadrement légal, Cowansville 2008, p. 165.

${ }^{21}$ A. Roy, Affaire Éric v. Lola : Une fin aux allures de commencement, (2013) 1 C.P. du N. 259, 294.

${ }^{22} \mathrm{~A}$. Roy, referenced above, notes 73, 302 and following ones

${ }^{23}$ For details, see B. Lefebvre [and] B. Moore, Contexte et enjeux d'une réforme de la conjugalité et de la filiation par procréation assistée en droit québécois, în Regards croisés sur le droit familial belge et québécois, N. Gallus (editor), Limal 2016, pp. 18-19.

${ }^{24}$ The dissident member proposes that the spouses, married or factual, be subject to the alimony obligation and to the rules for the division of the family's patrimony if they are the parents of a same child (Roy, Comité consultatif ..., cit.supra, p.77 sqq.). The Council for the Status of Women abundantly proposes in the same line of thought focusing on dissidence. He recommends extending the alimony obligation and the rules concerning the family patrimony to the factual spouses after two years of cohabitation or starting from the moment in which they become the parents of the same child, granting their possibility to escape the applicability of its rules (Roy, Pour ..., cit.supra, pp.77-78).

${ }^{25}$ Roy, Pour ..., cit.supra,, pp. 93-136. 
${ }^{26}$ Roy, Pour ..., cit.supra,, pp. 137-197.

27 The acquisition society would become a conventional regime.

${ }^{28}$ Roy, Pour ..., cit.supra,, pp. 154-159.

${ }^{29}$ A series of other changes in favor of the factual spouses are proposed as well: allowing donations in the event of death within the union contract, stabilizing the rules concerning life insurance, the allocation of the family home and of the household goods if the concerned is a will inheritor and the suspension of the prescription between the factual spouses over the course of the cohabitation.

${ }^{30}$ Currently, article 61.1 of the Law of interpretation, L.R.Q. c. I-16, defines the factual spouse as follows: „Factual spouses are to be considered as having the status of married couples, unless the specific context opposes such a qualification. Factual spouses are in fact two persons, of opposite or same gender, who live a common life and present themselves to public life as a couple, regardless - except for the presence of a provision to the contrary - of the duration of their cohabitation. If, in the absence of a legal criteria that would acknowledge the factual union, a controversy arises in respect to the existence of the life community, this is presumed as soon as the involved persons are have been in a status of cohabitation for over a year or from the moment in which the become the parents of the same child." This article applies to the Civil Code.

${ }^{31} \mathrm{~J}$. Goody, Familia europeană. O încercare de antropologie istorică, translated into Romanian by S. Doboş, laşi 2003, p. 200. See also C. Rada, Valori identitare ale familiei româneşti contemporane în contextul globalizării - o abordare antropologică, Bucharest 2013, pp. 53-57; INSEE, De plus en plus des petites menages dans les régions, in JCP-N (70) 2012, 27, Act.710. For an approach of this issue in the field of international law, see M.S. Aguirre [and] A. Wolfgram, United Nations Policy and the family: Redefining the Ties that Bind. A Study of History, Forces and Trends, in BYU (16) 2001-2002, 2, pp. 113-178.

$32 \mathrm{P}$. Becqué, Evoluţia noţiunii de familie şi consecinţele acesteia în materie succesorală în dreptul francez, în Bob, Evoluţia..., cit.supra, pp. 157-158 (or the French version: L'évolution de la notion de famille et ses conséquences en matière successorale en droit français, în SUBBiur. (59) 2013.2.120-121, http://studia.law.ubbcluj.ro/articol/552).

${ }^{33}$ C. Neirink, La présomption de paternité ou la nouvelle bataille d'Hernani, în Mélanges Spiteri, vol. II, p. 828.

${ }^{34}$ A. Giddens, Sociologie ${ }^{5}$, translated into Romanian by O. Gheorghiu, Bucharest 2010, p. 201.

${ }^{35}$ Here we revisit the abridged aspects extracted from J-L. Renchon, Ce viziune există asupra familiei în dreptul succesoral belgian?, în Bob, Evoluţia, pp. 61-79 (French version: Quelle vision de la famille en droit belge des successions?, în SUBBiur. 2013.2.44-58, http://studia.law.ubbcluj.ro/articol/548. See as well P. Delnoy, Les libéralités et les successions. Précis de droit civil ${ }^{4}$, by P. Moreau, Bruxelles 2013, pp. 251-253. For the legal regime in force before the reform of 1981, see the work of M. Gagné, Rapport général, in Les procédés de défense des intérêts patrimoniaux de la famille légitime - Journées canadiennes, Travaux de l'Association Henri Capitant des amis de la culture juridique française. T. XII, 1958, Paris 1961, pp. 86-87.

${ }^{36} \mathrm{~J}$-L. Renchon, in J-L. Renchon [and] F. Tainmont, Le statut patrimonial du conjoint survivant. Actes de la $5^{e}$ Journée d'études juridiques Jean Renauld, Bruxelles 2004, pp. 11-12.

37 Delnoy, op.cit., p. 240. The successional reform of 1981 was also catalyzed due to the legislative measures that, in 1958 and 1976, were introduced to alleviate the personal and patrimonial status of the wife within the family (see J. Fillenbaum, in ***Précis du droit des successions et des libéralités, ACh. Van Gysel (editor), Bruxelles 2008, p. 55).

${ }^{38}$ M. Ioniţă-Niculescu, Căsătoria şi familia în nordul Olteniei în a doua jumătate a secolului al XIX-lea şi începutul secolului XX, Cluj-Napoca 2012, p. 105. Also see M. Brie, Familie şi societate în nordvestul Transilvaniei (a doua jumătate a secolului al XIX - începutul secolului XX), Oradea 2008, pp. 348-367 and 425. 
${ }^{39}$ Brie, op.cit., pp. 348-350.

${ }^{40}$ See D. Burian, Emanciparea femeii şi rolul ei în problema divorţului în a doua jumătate a secolului al XIX-lea în Transilvania, in . Bolovan [and] D. Covaci [and] D. Deteşan [and] M. Eppel [and] E.C. Holom, În căutarea fericirii - Viaţa familială în spaţiul românesc în sec. XVIII-XX, Cluj-Napoca 2010, p. 54; D. Deteşan, S. Retegan, Sub focul încrucişat al bisericii şi statului: Concubinajul la românii din Transilvania între 1850-1895, in Bolovan, Covaci..., În căutarea... cit.supra, pp. 83-90.

${ }^{41}$ Deteşan, Retegan, op.cit., pp. 94-95.

${ }^{42}$ I. Bolovan, S.P. Bolovan, Familia în Europa Centrală în timpul primei tranziţii demografice, in Bolovan, Covaci..., În căutarea... cit.supra, pp. 297-298.

${ }^{43}$ A. Băran-Pescaru, Familia azi. O perspectivă socio-pedagogică, Bucharest 2004, p. 8. The phenomenon was not completely new, as it had manifested itself following the First World War as well (see I. Bolovan [and] S.P. Bolovan, The impact of World War I on the Family in Transylvania, in A. Fauve-Chamoux [and] I. Bolovan (editor), Families in Europe between the 19th and the 21st centuries - From the traditional model to contemporary PACS, Cluj-Napoca 2009, pp. 619-626).

${ }^{44}$ For an analysis of the diminished religious adherence of those socialized before 1989 , also see Rada, op.cit., pp. 139-140.

${ }^{45}$ See details in Ioniţă-Niculescu, op.cit., p. 92.

${ }^{46}$ Băran-Pescaru, op.cit., p. 14.

${ }^{47}$ For details see Goody, op.cit., pp. 187-190.

${ }^{48}$ Legally-validated alternative offered by Statute 210/31 Dec. 1999 regarding the paternal leave.

${ }^{49}$ The child becomes a mere "family member with an own potential to become autonomous (Ariès, 1980)." (see A. Gavreliuc, Cercetări asupra tiparelor valorice şi atitudinale, in Tr. Rotariu [and] V. Voineagu (editor), Inerţie şi schimbare. Dimensiuni sociale ale tranziţiei în România, Bucharest 2012, p. 296).

50 "The decline in good jobs for men and the increase in the numbered of employed women reduced economic dependency and has eroded the patriarchal basis of the modern family" (Băran-Pescaru, op.cit., p. 165). See as well C. Ciupercă, Cuplul modern, între emancipare şi disoluţie, Alexandria 2000, pp. 144-155 ; B. Szabò, Transformări de roluri conjugale la familiile din România, Cluj-Napoca 2009, pp. 113-119; P-T. Hărăguş, Folosire timpului şi distribuţia sarcinilor domestice în familia din România, ClujNapoca 2010, pp. 151-203.

${ }^{51}$ L. Dumănescu, Familia românească în comunism, Cluj-Napoca 2012, p. 19.

${ }^{52}$ Ciupercă, op.cit., pp. 275-290.

53 Dumănescu, op.cit., pp. 83-84 şi p. 152.

${ }^{54}$ Ciupercă, op.cit., p. 285. An identical conclusion regarding the importance of family in Romania found in R. Popescu, Introducere în sociologia familiei. Familia românească contemporană, Bucharest 2009, pp. 75, 102 and 181. The persistence of the village-type traditional way of life in the urban landscape explains the nostalgic-propagandistic literature of the type contained in $R$. Gheorghiu, Familia sătească altădată şi astăzi, Bucharest 1977.

${ }^{55}$ Also see Popescu, op.cit., p. 102.

${ }^{56}$ T. Turai, Towards nuclear family?, in Fauve-Chamoux, Bolovan, Families, cit.supra, pp. 155-166.

${ }^{57}$ I. Chirilă, The struggle for recognition or the victorious slave (Incursion in the sphere of legal and theological definition of the family), JSRI (27) 2014, 13 http://jsri.ro/ojs/index.php/jsri/article/view/726.

58 We do not place the notion of "traditional family" between brackets in order to minimize it or in order to refer to a speech, but rather due to nowadays tendency to the mythicizing of the concept in Romania, a result of an insufficient awareness as to its meaning.

${ }^{59}$ Goody, op.cit., pp. 196-198. 
${ }^{60}$ For details and explanations regarding this conclusion, see M. Voicu, Religiosity and religious revival during the transition period in Romania, in The values of Romanians: 1993-2006. A sociological perspective, B. Voicu [and] M. Voicu (editors), Bucharest 2008, in correspondence with the abridged conclusions found at pp. 165-166.

${ }^{61}$ Al. Otetelişanu, Curs de drept civil comparat. Materia specială. Dreptul de succesiune al soţului supravieţuitor în dreptul comparat, (lito), Bucharest 1947, pp. 272-280; M. Constantinescu, Familia românească între tradiţie şi modernitate. Studii şi cercetări, Piteşti 2008, pp. 8-10; Delnoy, op.cit., p. 239.

${ }^{62}$ Constantinescu, op.cit., pp. 9-10. Also see the remarks contained in Popescu, op.cit., pp. 27-28, 34 and 39.

${ }^{63}$ Popescu, op.cit., p. 41.

64 The same general conclusion for the Italian law showcased by M. Dossetti, in Delle successioni vol. II (2010) art. 565-712, editor V. Cuffaro [and] Fr. Delfini, in Commentario del Codice civile, E. Gabrielli (editor), Torino 2009, pp. 7-8.

${ }^{65}$ Popescu, op.cit., with the synthetic conclusions from p. 191; C. Pădurean, Family in Romania during the Communist Regime, in Fauve-Chamoux, Bolovan, Families, pp. 521-542 and 535; A. Dohotariu, The Evolution of Young Couples among Young Romanians, in Fauve-Chamoux, Bolovan, Families, pp. 766776; C. Mureşan, Schimbările comportamentului familial în România - o abordare din perspectiva cursului vieţii, Cluj-Napoca 2012, p. 177; Gavreliuc, op.cit., p. 295. There are many sociological and psychological analyses on these matters: e.g., Constantinescu, op.cit., pp. 116-138.

${ }^{66}$ Popescu, op.cit., p. 73; Tr. Rotariu [and] C. Mureşan [and] M. Hărăguş [and] P.T. Hărăguş, Căsătoria şi reproducerea populaţiei, in Voineagu, Inerţie..., cit.supra, pp. 125-126; Gavreliuc, op.cit., p. 294.

${ }^{67}$ Popescu, op.cit., p. 138. For the statistic of the relative size, duration and consequences of cohabitation in respect to marriage, see Rotariu, Mureşan ..., op.cit., pp. 128-129.

${ }^{68}$ For a plea of legislative permissiveness for the homosexual marriage allowance, in spite of the official arguments of the ROC, see C. Băra, Reflecţii asupra dreptului familiei şi succesiunilor în contextul noilor relaţii sociale, in BNP (17) 2013, 5, p. 110.

${ }^{69}$ P. Iluţ [and] V. Cioflică [and] L. Nistor [and] C. Tîrhaş, Familia monoparentală în România: comparaţie urban-rural, in ***Familia monoparentală în România şi fenomene conexe, P. Iluţ (editor), Cluj-Napoca 2009, p. 29.

${ }^{70}$ Also see M. Dosetti, op.cit., p. 11.

${ }^{71}$ G. Brière, Droit des successions ${ }^{3}$, revăzută şi actualizată de J. Beaulne, Montréal 2002, pp. 137-149.

72 P-H. Steinauer, Le droit des successions, Berna 2006, pp. 83 and 85.

${ }^{73}$ Steinauer, Successions [original French wording Successions], pp. 67 and mostly 81.

${ }^{74}$ For a criticism of the solution, see M. Eliescu, Moştenirea şi devoluţiunea ei în dreptul RSR, Bucharest 1966, p. 337, with the case law and authors referenced therein. Its criticism - valid under the regulation of the Romanian Civil Code of 1864 - cannot be accepted past the 1st of October 2011. The New Code has (re)introduced disinheritance, whose effect is eliminating the possibility of the benefit of the heritage, and not the loss of the status of heir (Fr. Deak, R.Popescu, Tratat de drept succesoral, vol. II, Bucharest 2014, p. 185).

${ }^{75}$ The preference granted to descendants of a further away degree of the brothers and sisters to the detriment of the grandparents was considered as worthy of criticism even by Eugen Huber, the drafter of the Swiss Code. He finally preferred it due to reasons solely related to technical simplicity (see V. Rossel, F.-H. Mentha, Manuel de droit civil suisse, vol. II Des successions - Des droits réels: $1^{\text {re }}$ partie [De la propriété $]^{2}$, Lausanne-Geneva 1922, pp. 8-9).

${ }^{76}$ As was also decided through the French successional reforms, in 2001 and 2006 (v. S. Gaudemet [and] Fr. Terré [and] Y. Lequette, Droit civil. Les successions. Les libéralités, Paris 2013, pp. 637-639 no. 724-725). 
${ }^{77}$ C. Negrea, Dreptul de moştenire ab intestat între soţii căsătoriţi, in Drepturile femeii în vitorul cod civil - Studii, comunicări şi propuneri. Raport de C.C. Botez (editor), Bucharest 1924, p. 128.

${ }^{78}$ Another author also proposed (following the enactment of the 1944 reform) rights in usufruct when competing against the descendants, but this time without taking into account the chosen matrimonial regime (Otetelişanu, op.cit., p. 235).

${ }^{79}$ Id., pp. 131-132.

${ }^{80}$ A. Cerban, Trăsăturile esenţiale ale regimului succesoral ab intestat în Noul Cod Civil - studiu critic si comparat, Bucharest 1940, p. 17.

${ }^{81}$ Consiliul Naţional al Femeilor Române. Comisiunea legislativă, Drepturile femeii în vitorul cod civil - Studii, comunicări şi propuneri în vederea reformei. Raport de C.C. Botez (editor), Bucharest 1924, p. 174.

${ }^{82}$ I. Popescu Copuz, Despre succesiunea între soţi, C.Jud. (16) 1933, 39, pp. 614-615.

${ }^{83} \mathrm{~F}$. Tainmont, La protection du conjoint survivant, entre réserve et secours alimentaire, bilan et perspectives, în Renchon, Tainmont, op.cit., p. 307.

${ }^{84}$ See the results of recent sociological inquiries in Rada, op.cit., pp. 89-93.

${ }^{85}$ Ciupercă, op.cit., p. 138.

${ }^{86}$ For similar arguments see M. Dosetti, op.cit., pp. 8-11.

87 Professor Francisc Deak used to insist especially to this end (see Fr. Deak, Tratat de drept succesoral, Bucharest 2002, p. 118 the last paragraph of the reference that continued from page 117).

${ }^{88} \mathrm{P}$. Catala, La veuve et l'orphelin, in *** L'honnête homme et le droit [Mélanges Jean-Claude Soyer], Paris 2000, p. 65.

${ }^{89} \mathrm{Cf}$. P. Delnoy, Rapport belge, in Aspects récents de l'évolution du droit de la famille - Journées turques, in Travaux de l'Association Henri Capitant des amis de la culture juridique française. T. XXXIX, 1988, Paris 1990, p. 192 (where he characterises this means of structuring the family patrimonies as being a "democratization of personal worths"); Delnoy, Successions, p. 241.

${ }^{90}$ It is the first step before the establishment of the successional mass, according to the decision of the former Supreme Court: TS civ., dec. 452/16 mart. 1960, in CD 1960, p. 259. Also see M. Moretti, in Delle successioni..., cit.supra, p. 88.

${ }^{91}$ On the dynamics of this process, see details in Tr. Rotariu [and] E. Mezei, Populaţia României. Volum, structuri şi procese demografice, în Rotariu, Voineagu, Inerţie..., cit.supra, pp. 17-44 and 33-39.

${ }^{92}$ I. Niculescu-Aron [and] V. Voineagu [and] C. Mihăescu [and] R. Căplescu, Gospodăriile de vârstnici din România: în grija statului sau a familiei?, in RRS (7) 2010, 12, p. 19; Mureşan, Schimbările..., cit.supra, pp. 233-238 and 247.

${ }_{93}$ M.D. Bob, Ce se poate face pentru a mulţumi soţul supravieţuitor?, in Bob, Evoluţia..., cit.supra (French version Qu'est-ce qu'on peut faire pour contenter le conjoint survivant?, în SUBBiur. (59) 2013.2.90-98, http://studia.law.ubbcluj.ro/articol/551), pp. 132-133.

${ }^{94}$ At the respective moment of the drafting process of the Romanian New Civil Code, The Canadian Commission led by Professor Jean Pineau would visit Bucharest on a monthly basis, in order to work with us directly using the model of the 1994 Québec Civil Code.

${ }^{95}$ At the end of every article, the sources concurring for its drafting appear between parentheses: the bold ones signify the exact replication of the source-text, while the regular font signify the fact that the source merely provided inspiration for the drafting of the respective article. The French texts are rendered in their numbering resulted from the reform of 2001.

${ }^{96}$ Namely Marian Nicolae, Bogdan Dumitrache and Bogdan Pătraşcu.

${ }^{97}$ It appears that the same phenomenon took place during the drafting of the Romanian Civil Code of 1940 as well: „Probably the inherent economic inconveniences pertaining to the usufruct determined the lawmaker to grant the surviving spouse a successional right to full ownership” (Cerban, op.cit., p. 18).

${ }_{98}$ M. Donnier, Nature de la réserve héréditaire, Dalloz 1977.J.541. 
${ }^{99}$ Otetelişanu, op.cit., p. 235; J. Fillenbaum, op.cit., p. 58.

100 Otetelişanu, op.cit., p. 236.

${ }^{101}$ See I.P. Muşica, Observation -lalomiţa Tribunal $1^{\text {st }}$. section, civ.dec. 130/1937, in Jur.Gen. (17) 1939.366.349. Also see the arguments against this solution, raised in Otetelişanu, op.cit., pp. 239-241.

${ }^{102}$ Fillenbaum, loc.cit.; P. Caignault, Protéger le conjoint survivant. Le recours aux libéralités: anticiper les difficultés liquidatives - Cas pratiques, in JCP-N (73) 2015, 22, 1169.

${ }^{103}$ Art. 914-1 Fr.civ.c. (see M-C. Forgeard [and] R. Crône [and] B. Gelot, Le nouveau droit des successions et des libéralités. Loi du 23 juin 2006, commentaries et formules, Paris 2007, p. 13 ; Gaudemet..., Droit..., cit.supra, pp. 636-639 no. 722-725).

${ }^{104}$ Gaudemet..., op.cit. pp. 641-645 no. 728-730.

${ }^{105}$ For opinions for and against, see Otetelişanu, op.cit., p. 250.

${ }^{106} \mathrm{~A}$ situation which can be noticed as well in the differences between the successional regimes throughout the EU states (also see the specific examples from UINL, Régimes matrimoniaux, successions et libéralités dans les relations internationales et internes, M. Verwilghen [and] $\mathrm{S}$. Mahieu [editor], Bruxelles 2007).

107 Popescu, op.cit., p. 42.

${ }^{108}$ Also see A. Mascheroni, in Delle successioni vol. I (2009) art. 456-564, V. Cuffaro [and] Fr. Delfini (editor), in Commentario del Codice civile E. Gabrielli (editor), Torino 2009, p. 530.

${ }^{109}$ A. Mascheroni, op.cit., p. 557.

110 Also see Delnoy, Rapport..., cit.supra, p. 195.

${ }^{111}$ P. Catala, Actualité du Code civil, in Droit et actualité [Etudes offertes à Jacques Béguin], Paris 2005, pp. 65-66.

112 "The notary public is often times faced with the clients' request to find a possibility to transfer the property right among relatives, by means of which both the weak party should be protected by retaining at least a right to use the good, as well as the part receiving the ownership should be protected in the future by the potential requests of other relatives which are not pleased with this convention and to whom the law provides legal means to reinstate their rights. Thus, the notary stands between the professional and moral duty to protect the seller and that of backing the acquirer's standing in respect to third parties." (T.I. Coman, Art. 1091 alin. (4) C.civ. Mostră a interferenţei dreptului succesiunilor cu dreptul contractelor sau probleme cotidiene în practica notarială, izvorâte din aspects teoretice, in BNP (19) 2015, 6, pp. 58-59). Cf. M. Cazan, Interpretări (soluţii) practice cu privire la prezumţia de donaţie instituită de art. 1091 alin. (4) Cod civil, in BNP (19) 2015, 2, pp. 17-18.

${ }^{113}$ See the countries that were enumerated to this end in the previous chapter.

${ }^{114}$ According to S. Arnaud, Les conséquences de la réduction en valeur, in JCP-N (71) 2013, 47, 1270 p. 51.

${ }^{115}$ As it is proposed in the Italian scholarly research literature (G. De Rosa, in Delle successioni vol. I, cit.supra, p. 541).

${ }^{116}$ As it takes place, for example, in the Italian successional law. Even so, the reserve is criticized in Italy for the uncertainty it generates, up to the passing of the twenty years time, for the good faith third party acquisitor of the donated immovable (G. De Rosa, op.cit., p. 540).

${ }^{117}$ Băran-Pescaru, op.cit., p. 9. 